\title{
Comparative analysis of the effects of institutional factors and Piketty's Hypothesis on inequality: evidence from a panel of countries
}

\author{
Ali Sarkhosh-Sara, Khadije Nasrollahi", Karim Azarbayjani and Rasul Bakhshi Dastjerdi
}

${ }^{*}$ Correspondence:

kh.nasrolahi@ase.ui.ac.ir

Department of Economics,

University of Isfahan,

Hezarjerib St, Azadi Square,

Isfahan, Iran

\begin{abstract}
There are many reports on investigating the influences of institutional factors and Piketty's Hypothesis on income inequality; nonetheless, the inequality effects of both factors are seemingly investigated separately. We hypothesize that economic freedom viewed as an institutional improvement or distortion has comparatively larger effects on inequality than the forces of income divergence introduced by Thomas Piketty. This article revisits the income inequality- $(r-g)$ nexus and uncovers the role of economic freedom as an institutional indicator in explaining the relationship. Considering the latest inequality data of World Inequality Database (WID) and Standardized World Income Inequality (SWIID) for 82 countries over 2000-2017, an inequality model is estimated that explicitly captures the interaction effect of $(r-g)$ and economic freedom. Reaffirming that economic freedom affects inequality in a non-linear form, we also found evidence that $(r-g)$ raises inequality in the short run, demonstrating that preexisting holders of capital derive greater shares of income. Nevertheless, the effect of $(r-g)$ is not as strong as that of economic freedom and is insignificant in highly unequal countries. This implies that institutional factors play a more important role than Piketty's Hypothesis in the presence of high inequality. Furthermore, variables of inflation, gross savings rate, trade openness, and unemployment rate are shown to be the most consistently positive and significant factor and GDP per capita, government spending, natural resource rent, and tax revenue variables have negative and significant effects on the baseline estimations.
\end{abstract}

Keywords: Economic freedom, $(r-g)$, Income inequality, Piketty

\section{Introduction}

Due to the 2008 financial crisis, the topic of factors underlying inequality, has experienced a marked revival in the last decade. The arguments over the structure and causes of inequality abound not only in the economic mainstream, but also in policy discussions. This discourse has been motivated by the growth of inequality not only in the developed and industrialized world, but also in countries enjoying a developing economy and the potential consequences remain to be a common concern. While there is

(c) The Author(s) 2020. This article is licensed under a Creative Commons Attribution 4.0 International License, which permits use, sharing adaptation, distribution and reproduction in any medium or format, as long as you give appropriate credit to the original author(s) and the source, provide a link to the Creative Commons licence, and indicate if changes were made. The images or other third party material in this article are included in the article's Creative Commons licence, unless indicated otherwise in a credit line to the material. If material is not included in the article's Creative Commons licence and your intended use is not permitted by statutory regulation or exceeds the permitted use, you will need to obtain permission directly from the copyright holder. To view a copy of this licence, visit http://creativeco mmons.org/licenses/by/4.0/. 
a growing consensus that inequality results in severe social stratification and can upset economic demand in the long term, it thus turns into a question of how to appropriately address it by teasing out the underlying structural causes (Fakir et al. 2017).

The roots of inequality can be traced back to the internal contradictions of the capitalistic society in the sense that the market mechanism itself leads to inequality. This is the view held by Marx and Ricardo, who formulated various laws that take account of the internal processes of the capitalistic system and how they propel inequality (Ricardo 1817; Marx 1867). Inequality can be viewed as a product of the changes in the democratic structures, laws, taxes, and institutions. This "institutional" approach intends to account for the emergence of inequality by studying the various institutional structures (Acemoglu and Robinson 2015). In this context, the economic and political institutions are produced by the endogenous distribution of political power, causing different income distributions. This explains the failure of political and economic institutions to control rent-seeking behavior that results in growing inequality. As a result, inequality derived from the poor institutional quality can be mainly considered as the failure of institutions to operate appropriately. Conversely, Piketty's second fundamental law is tantamount to Marx and Ricardo's notion of inequality as an inherent characteristic of a capitalistic economy.

Among the various institutional quality indicators, economic freedom is a more important index for institutional quality. In the present study, we used economic freedom as an indicator of institutional quality in relation to cross-country income inequality, like Gwartney et al. (2004). The economic freedom index reflects the key elements of the institutional quality (Gwartney and Lawson 2003). In addition to growth, economic freedom is also a function of inequality across different nations. Investigating the possible influences of economic freedom on income inequality has been profusely undertaken by numerous researchers; however, the empirical evidence to support the findings remains to be at best variation. On the one side, higher economic freedom might be traced back to lower taxes and welfare expenditures, which are likely to have negative consequences to the low-income, on the other side, higher degrees of economic freedom may drive growth and lift the legal impediments that favor politically privileged groups and create economic opportunities to less privileged groups and lower income individuals (Perez-Moreno and Angulo-Guerrero 2016). De Soto (2000) contends that capital is the engine of labor productivity, and creates the wealth in developed countries. We contend in the present article that one of the primary determinants of inequality in any society is the level of economic freedom it offers. We postulate that through compromising the basic mechanisms of redistributive policy, economic freedom provides an environment in which inequality is likely to emerge; however, given the degree of economic freedom, this outcome can be changed (Bennett and Nikolaev 2017). Accordingly, we regard the latest progress in the field of inequality by exploring Piketty's Hypothesis. This is of special interest to us as the second fundamental law proposes that inequality is a common feature of capitalism. If the second fundamental law holds, it implies that the effective functioning of capitalism is what drives inequality, along with distortive means such as institutional failure and economic freedom. In such a case, it is worth studying if the distortions induced by economic freedom are more involved than the returns to capital caused by functioning markets. 
The rest of the paper is organized as follows. Section 2 reviews the literature on the theoretical links of economic freedom and Piketty's Hypothesis to inequality. Section 3 discusses estimation method and data. Section 4 undertakes econometric specification and empirical estimates. Section 5 discusses the estimation results and Sect. 6 concludes with some policy implications.

\section{Literature review}

\subsection{Economic freedom and inequality}

A favorable model to analyze inequality was considered for both of the potential impacts of various institutions on the allocation of resources and the evolution of these institutions by Fakir et al. (2017) confirms that in societies characterized using the highest levels of inequality, the pure dynamics of capitalism itself is not the dominant institutional, but there are other equally important factors. Constantine (2017) states that increased inequality is the probable result of structural changes away from rising returns of production structures. Most probably, inequality will likely touch such high levels in case there is either systemic neglect on the part of the state in addressing inequality or cultural permission or indifference in the face of the corrupt moral codes which tolerate inequality (Fakir et al. 2017). The nature of taxation systems, as well as the extent to which individuals can influence these systems through political power allowed by the constitution, is stressed in Acemoglu and Robinson (2015) as one of the key determinants of inequality.

Stiglitz (2012) claimed that manipulation of the market and unfair policies through the underlying inequality in economic and political force allowed the top $1 \%$ of the income distribution to earn an excessive share of economic growth in the United States for the last 30 years. This interpretation is in line with Roine et al. (2009), who showed that the high economic growth through the last decades has been largely advantageous to richincome groups. The rise in GDP did not trickle down, something which holds equally for continental European countries and Anglo-Saxon. However, opposite to the AngloSaxon countries, rising trade has not led to a further rise in the very high incomes in Europe within the population class of the richest $10 \%$. According to Roine et al. (2009), this is because of powerful labor market institutions and the equalizing performance of the government. This analysis shows that inequality is linked to government institutions and hence to (different dimensions of) economic freedom.

Studies that scrutinize the association between income inequality and economic freedom, include those by Carter (2007), Berggren (1999), Ashby and Sobel (2008), Scully (2002), and Apergis et al. (2014). Apergis et al. (2014) studied the association between economic freedom and income inequality across the US. Their findings document a bi-directional causality among income inequality and economic freedom in both the long- and short-run. Applying an unbalanced panel of 126 countries and the economic freedom index, Carter (2007) shows that higher levels of economic freedom can enhance income equality by increasing income-earning possibilities, but also decrease equality by decreasing income redistribution opportunities. He discovers that the recent effect outweighs the former except at considerably low levels of freedom; hence, it implies a tradeoff between income equality and economic freedom, with the influence of economic freedom rising at greater levels of freedom. Clark and Lawson (2008) examine the role of 
tax policy on income distribution, and they document evidence in support of improved income equality due to progressive taxation with high top marginal tax rates. Ashby and Sobel (2008) study the link between income distribution and economic freedom across the US states applying the Economic Freedom of North America Index (EFNA), as proposed by Karabegovic and McMahon (2005). Their results demonstrate that rise in economic freedom match with lower inequality.

However, the less privileged people in developing countries are not devoid of assets, but as there exist no clear-cut property rights, such assets could not be converted into capital. As a result, economic freedom can give rise to economic opportunities to the poor, and thus it can reduce income inequality (Islam 2018). Borrowing Gini coefficients from the Deininger and Squire's (1996) database, Berggren (1999) reported a positive correlation between changes in income equality and economic freedom, implying that ongoing gradual increases in the degree of economic freedom result in increasing equality levels in the long run. After breaking down the composite economic freedom measure into smaller components, Berggren (1999) asserts that the components of economic freedom do not bear on equality; only the liberalization of trade and financial mobility were observed to promote equality. Recently, Scully (2002) claims that economic freedom fosters higher equality in the presence of a marginal trade-off between income inequality and growth. Utilizing Fraser Institute's revised dataset of Economic Freedom of the World and the new and expanded income inequality (Gini coefficients) dataset of the UNU/WIDER, Carter (2007) provides contradictory evidence that economic freedom raises income inequality. Accordingly, higher levels of economic freedom could cause higher income equality by expanding income-earning opportunities. On the other hand, it can threaten equality by lowering income redistribution to the detriment of the needy, although empirical data support the dominance of the latter outcome with the exception of comparatively lower degrees of economic freedom. Moreover, deregulation and social globalization worsen inequality. Reforms in the direction of economic freedom are likely to aggravate inequality especially in affluent countries, and social globalization is necessary in underdeveloped countries. Perez-Moreno and Angulo-Guerrero (2016) observed that high degrees of economic freedom (overall and government size) are heavily linked to higher income inequality in the EU for the 2000s. In comparison with Carter (2007), Bennett and Vedder (2013) reported an inverted U-shaped association between economic freedom and income inequality for 50 US States from 1979-2004. They offered ample evidence in support of the observation that rises in economic freedom that corresponds with lower income inequality. Nonetheless, they also presented compelling evidence confirming that the association is a function of the initial level of economic freedom. This implies that this relationship is probably a non-linear one, similar to the inverted U-shaped relationship, whose inflection point is explicitly determined. Yet, Sturm and De Haan (2015) do not report any strong correlation between income inequality and economic freedom for a panel of 108 countries from 1971 to 2010. Apergis and Cooray (2015) employed linear and non-linear co-integration techniques to recognize a long-term equilibrium association between income inequality and economic freedom for both the total and main areas of the economic freedom composite index for 138 countries. The linear long-term parameter estimates confirm that the relationship is highly likely to be negative, whereas the non-linear long-term parameter estimates 

$\left.\begin{array}{l}\text { Political institutions } \mathrm{t} \Rightarrow \text { de jure political power } \mathrm{t} \\ \text { Inequality } \mathrm{t} \Rightarrow \text { de facto political power } \mathrm{t}\end{array}\right) \Rightarrow$ Economic Freedom $\mathrm{t} \Rightarrow$ (technology $\mathrm{y}_{\mathrm{t}}$, skills $\mathrm{s}_{\mathrm{t}}$, and prices $\left._{\mathrm{t}}\right\}$

$\Rightarrow$ Economic performance $t$ $\Rightarrow\left\{\begin{array}{r}\text { inequality } t+1 \\ \text { Ecomatis }\end{array}\right.$

Fig. 1 Linking of institutions with inequality

demonstrate that beyond a threshold level, the link between economic freedom and income inequality is negative. However, below this threshold level, the relationship happens to be positive. In summary, this discussion in the analytical framework of Acemoglu and Robinson (2015) can be understood as provided in Fig. 1.

\subsection{Piketty's forces of divergence}

Capital in the Twenty-First Century, Thomas Piketty's masterpiece, has been highly admired because it synthesized and presented in a well-timed and easily accessed fashion the findings of more than a decade-long research led by Piketty and his colleagues. No doubt, his efforts will continue to inspire the researchers in the future, not only in terms of the databases he compiled, which represent the (traditionally scarce) information about income inequality, but also for it encourages the economists to adopt the estimation techniques they introduced. Piketty's theoretical accounts of the changes in the patterns of inequality are appealing. In short, he holds that with all the other things being constant, whenever the gap between the rate of returns on capital ( $r$ ) and the output growth rate $(\mathrm{g})$ rises, so does the share of capital in national income. Moreover, since capital income often has a more unequal distribution compared to labor income, any rise in the share of capital would probably result in an augmentation in the overall income (and, in the long run, wealth) inequality. These are both viable relationships, however, embedded in rich data, Capital offers no formal empirical evidence in support of these extrapolations. Indeed, there is something a little beyond the simple correlations the prospective reader is likely to infer in the charts including a greater number of aggregated multi-decennial averages.

The first fundamental law of capitalism states $\alpha=r \times \beta$, where $\beta$ signifies the wealthincome ratio and $\alpha$ describes the capital income share. The equation is a mere accounting integrity, as Piketty notes. This equation says that the capital income share equals the product of the interest rate and the wealth-income ratio. The second fundamental law of capitalism knows $\beta=s / g$, where s denotes the savings rate. This equation says that the wealth-income ratio equals the savings rate divided by the growth rate. The first law is merely an accounting integrity, according to which if the capital-to-income ratio increases, the percentage of income accumulating for the capital owner's increases, providing the rate of return on capital, $r$, does not fall. The second law is an equilibrium requirement showing that over time, the $K-Y$ ratio tends towards the $s-g$ ratio, in which $s$ is the saving rate, and $g$ is the growth rate in total real income. When these two laws are used in combination, the result is that capital's share of income is driven by $r \times s=g$. 
Piketty and Zucman (2014) claim that the share of capital, income inequality, and wealth inequality remains to be the growing functions of $(\mathrm{r}-\mathrm{g}) .{ }^{1}$ Assuming Piketty to be right, then it is expected that the variations in the share of capital to be accounted for by the contemporaneous and old variations in the spread between $r$ and $g$. Piketty proceeds to state that since the distribution of the returns on capital is not more equal compared to that of the labor income, a higher share of capital in the national income is likely to result in higher income and wealth inequality (Piketty 2014). But the full significance of rising $\beta$ becomes clear only when it is linked with Piketty's first fundamental law of capitalism and one basic inequality relation. The first fundamental law says that the share of capital incomes in national income $(\alpha)$ is equivalent to the real rate of return on capital $(r)$ multiplied by $\beta$. Now, if the rate of return on capital continues forever over the rate of growth of the economy $(g)$, then $\alpha$ rises by definition. This, connected with the rising $\beta$, drives the share of capital in national income arbitrarily near to one. The process has a positive feedback circle: as $\alpha$ rises, not only do capital owners become richer, but, unless they use the entire return from their capital, more will stay for them to reinvest. The enhanced saving, in turn, makes the growth rate of capital go beyond the growth rate of national income and increases $\beta$. Thus, not only does higher $\beta$ result in higher $\alpha$, but higher $\alpha$ also results in greater $\beta$. The model, nevertheless, crucially relies on the inequality association $r>g$. If $r=g$, then national income and capital rise at the equal rate, $\beta$ is constant, and the share of capital in total product stays equal. Therefore, whether Piketty's method remains or breaks down turns on whether the evidence for $r>g$ is powerful enough or not (Milanovic 2014).

Although these arguments have fascinated the attention of a large number of researchers, there has also been a wave of criticism from the academics and policymakers. For example, Krusell et al. (2015) frown at the 2nd fundamental law, as it suggests savings behavior that is not grounded in empirical evidence. Piketty postulates that the net saving rate remains stable with declining growth. This postulation necessitates the gross saving rate to tend to one as g approaches zero, which appears rather unlikely. Jones (2015) holds that Piketty's expectation of growing wealth inequality rests on the shaky assumptions that differences in $r$ will not follow the differences in $g$, or the saving rate net of depreciation does not differ in time. Mankiw (2015) asserts that, for wealth inequality to increase constantly, $r$ has to considerably go beyond $g$ for almost $7 \%$ per year, if one is to explain the consumption behavior, generational wealth distribution, and wealth taxation. Weil (2015) posits that the analysis recommended by Piketty in his book concentrates on market wealth. Therefore, it does not consider all the aspects of wealth, especially human capital and wealth transfers that over the last 300 years. As a result, some criticize that Piketty does not place sufficient importance on one-off historical and institutional events (Kuttner 2014).

The economic world of Piketty is closed and unable to change. Piketty's second law needs a consistent net saving rate. His only argument is an inductive inference: the future is the reproduction of the past. It is unclear if it is right that the GDP growth rate in France, for example, increases and reducing the gap between $r$ and $g$, it is necessary to establish a diagnostic to realize the reason. The literature indicates that public

\footnotetext{
${ }^{1}$ Throughout this text $(r-g)$ represents the gap between the rate of return on capital (r) and the rate of economic growth $(g)$.
} 
expenditure and especially social spending (redistribution) have a negative influence on GDP growth rate (Facchini and Couvreur 2015). Studies have also regularly shown that economic freedom is positively connected to growth (Doucouliagos and Ulubasoglu 2006). Thus, economic stagnation also shows the continuing impact of socialist ideas on political elites, and it is not only for the failures of competitive market capitalism (Facchini and Melki 2014). If France, for example, decreasing the size of the government, it is possible that it will enhance its GDP growth rate and will reduce inequality under the second law of capitalism. Interventionism in this view usually becomes a force of divergence (Facchini and Couvreur 2015).

\section{Data}

The large majority of the macroeconomic data in the current paper was borrowed from the World Bank database. Net Gini, after the personal income tax was subtracted, the statistics were derived from the Standardized World Income Inequality dataset compiled by Solt (2014). The main problem with the Gini is that it fails to provide any knowledge on the structure of inequality and how it tends to evolve over time. In contrast, Piketty (2014) employed top centile and decile income shares to calculate inequality. We employed Gini because top decile income shares are not documented by the great proportion of developing countries in our dataset. Moreover, Acemoglu and Robinson (2015) assert that exclusive focus on top decile shares obscures the exact behavior of income distributions in the wider economy. However, to ensure the validity of our findings, our model is reported with top decile income shares in Sect. 5. The top 10\% income share data from the WID. ${ }^{2}$ The Economic Freedom in the World (EFW) dataset was derived from the Fraser Institute. ${ }^{3}$

The data related to good governance and other governance indices are borrowed from the World Bank's World Governance Indicator Dataset. Democracy indicators are derived from the Polity IV dataset measuring the quality of institutional democracy by examining different factors including frequency of selections, limitations on executive force, and the competitive nature of political participation, to name some. Finally, we obtained the data for other variables from the World Bank. The Corruptions Perception Index (CPI) collated by Transparency International. To inform the main purpose of this study, two sets of analyses are carried out, setting out with the potential impacts of economic freedom on inequality and proceeding to the impact of $(r-g)$ on inequality, as economic freedom is controlled.

The perceived lack of convergence in the variables of the study confirms the difference between countries and their institutional and social frameworks. Regarding the economic freedom scores, it was observed that the lowest score was that of Bangladesh in 2001, standing at 4.49, whereas Switzerland had the highest score of 8.73 in the same year. This clearly indicates the large gap between the developing and developed countries in our panel in their capability to control for economic freedom. Also, the greatest incidence of inequality in 2005 can be observed in Namibia with a value of 65.18 on the Gini Index. On the other end of the continuum, the lowest recorded Gini score of 21.61 in 2002 was obtained by Denmark. Although a low mean of 2.23 was obtained for

\footnotetext{
${ }^{2}$ World Inequality Database has been gathered and compiled by Piketty et al. https://wid.world/data/.

${ }^{3}$ https://www.fraserinstitute.org/studies/economic-freedom.
} 
$(r-g)$, its standard deviation is very high, standing almost at 8 . This is due to the existence of countries with either high-interest rates accompanied by negative growth rates or enormously high growth rates accompanied by negative interest rates. Thus countries need to be grouped according to their characteristics and economic structures. We follow the World Bank's classification (World Bank 2018) and classify the countries into three groups of high-, middle, and low-income countries according to their economic structures (Table 1).

\section{Estimation strategy}

To analyze and compare the association between economic freedom and Piketty's Hypothesis on inequality, we estimate the below model controlling for determinants of inequality:

$$
\text { Inequality }_{i t}=\beta_{0}+\beta_{1} E F W_{i t}+\beta_{2} E F W_{i t}^{2}+\beta_{3}(r-g)_{i t}+\beta_{4} E F W_{i t} \times(r-g)_{i t}+\sum_{i=1}^{9} \beta i \phi i t
$$

Economic freedom, shown by EFW, is the most important variable. A squared term for economic freedom is considered to examine its likely non-linear relationship with inequality, undertaken in the past by Bennett and Vedder (2013) and Ahmad (2017).

To explore Piketty's Hypothesis, we consider the variable $(\mathrm{r}-\mathrm{g})$, which is calculated as the real interest rate minus the rate of economic growth. Piketty (2014) assumes $r$ to be the real rate of return and applies the historical rate of almost $4 \%-5 \%$ for the analysis, allowing for the variation in growth. Conversely, Acemoglu and Robinson (2015) used real interest rates allowed to vary. Considering the examination of a large number of countries (not to mention the developing countries) in the short run, our measure of $r$ resembles the one provided by Acemoglu and Robinson (2015), thus enabling us to capture a considerable difference in real interest rates within our panel. Piketty (2014) states that $r$ is not limited to just real interest rates, but knowing that it is unlikely to accurately estimate a value for such an $r$, real interest rates can be used as an appropriate proxy for real returns to capital. Given that a large number of the nations in our panel are developing countries whose financial sectors remain underdeveloped, real interest rates are inclined to indicate the best feasible proxy available.

Whereas a more relevant measure of the returns to capital would be favored, our chosen proxy of interest has to at least present a minimum threshold for the influences of $(r-g)$ on inequality for the wide range of countries in the dataset. Following Krusell and Smith's (2015) argument, we also control the gross savings rate to make sure that we could include the influences of differential savings behavior as growth rates change. Therefore, we could control how variations in savings influence revenue from the capital and resulting income distribution. Furthermore, we intend to examine if the potential influences of the second fundamental law of capitalism are markedly higher for a given level of economic freedom. To embrace this effect, we consider the interaction between $(r-g)$ and economic freedom (EFW). Therefore, this interaction condition enables us to test if $(r-g)$ greatly affects the level of inequality for certain levels of economic freedom.

Also, $\phi i t$ denotes a vector of variables which consists of a panel of macroeconomic controls besides the institutional measures, for country $i$ and year $t$. Out of our 
Table 1 Descriptive statistics

\begin{tabular}{|c|c|c|c|c|c|c|c|}
\hline & Variable & Obs. & Mean & Std. Dev. & Min & Max & $\begin{array}{l}\text { No. } \\
\text { of countries }\end{array}$ \\
\hline \multirow{15}{*}{$\begin{array}{l}\text { Global panel } \\
\quad \text { (82 countries) }\end{array}$} & Net Gini & 1431 & 0.376658 & 0.086742 & 0.216132 & 0.651835 & 82 \\
\hline & Economic freedom & 1431 & 7.091903 & 0.669687 & 4.490000 & 8.730000 & 82 \\
\hline & $(r-g)$ & 1431 & 2.236555 & 8.307786 & -25.1359 & 101.6471 & 82 \\
\hline & GDP/capita & 1431 & 17569.13 & 19703.65 & 341.8498 & 91617.28 & 82 \\
\hline & $\begin{array}{l}\text { Govt. spending (as \% of } \\
\text { GDP) }\end{array}$ & 1431 & 16.15925 & 4.819181 & 4.845660 & 27.93502 & 82 \\
\hline & Inflation & 1431 & 4.912582 & 5.528758 & -4.47810 & 54.91537 & 82 \\
\hline & Population growth rate & 1431 & 0.923414 & 1.122950 & -9.08063 & 7.786010 & 82 \\
\hline & $\begin{array}{l}\text { Natural resource rent (as \% } \\
\text { of GDP) }\end{array}$ & 1431 & 3.244392 & 4.645688 & 0.000588 & 34.95626 & 82 \\
\hline & $\begin{array}{l}\text { Gross savings rate (as \% } \\
\text { of GDP) }\end{array}$ & 1431 & 22.72429 & 7.956617 & 1.725070 & 52.27694 & 82 \\
\hline & Tax revenue (as \% of GDP) & 1431 & 17.56361 & 6.140347 & 5.195323 & 48.56342 & 82 \\
\hline & Trade openness & 1431 & 80.63451 & 38.45180 & 19.79813 & 224.7553 & 82 \\
\hline & Unemployment rate & 1431 & 8.091996 & 5.419085 & 0.398000 & 33.47300 & 82 \\
\hline & Economic growth rate, $g$ & 1431 & 3.610366 & 3.457233 & -14.8141 & 25.11725 & 82 \\
\hline & Real interest rate, $r$ & 1431 & 5.846921 & 7.325907 & -20.3470 & 93.91508 & 82 \\
\hline & Top 10\% income share & 840 & 0.348870 & 0.090920 & 0.212768 & 0.600038 & 49 \\
\hline \multirow{14}{*}{$\begin{array}{l}\text { High-income } \\
\text { countries }\end{array}$} & Net Gini & 666 & 0.309885 & 0.056840 & 0.216132 & 0.530221 & 38 \\
\hline & Economic freedom & 666 & 7.555354 & 0.440993 & 6.000000 & 8.730000 & 38 \\
\hline & $(r-g)$ & 666 & 1.592174 & 6.844533 & -21.1672 & 101.6471 & 38 \\
\hline & GDP/capita & 666 & 33489.30 & 18892.38 & 5419.036 & 91617.28 & 38 \\
\hline & $\begin{array}{l}\text { Govt. spending (as \% of } \\
\text { GDP) }\end{array}$ & 666 & 18.94268 & 3.594081 & 9.925310 & 27.93502 & 38 \\
\hline & Inflation & 666 & 2.349375 & 2.265220 & -4.47810 & 19.37973 & 38 \\
\hline & Population growth rate & 666 & 0.491865 & 0.787962 & -3.84767 & 2.890960 & 38 \\
\hline & $\begin{array}{l}\text { Natural resource rent (as \% } \\
\text { of GDP) }\end{array}$ & 666 & 1.317635 & 2.898772 & 0.000000 & 21.39196 & 38 \\
\hline & $\begin{array}{l}\text { Gross savings rate (as \% } \\
\text { of GDP) }\end{array}$ & 666 & 22.68320 & 6.131523 & 4.870592 & 41.69065 & 38 \\
\hline & Tax revenue (as \% of GDP) & 666 & 20.69557 & 7.154102 & 7.936200 & 62.85861 & 38 \\
\hline & Trade openness & 666 & 95.33638 & 49.16110 & 19.79813 & 325.9982 & 38 \\
\hline & Unemployment rate & 666 & 8.002066 & 27.46600 & 2.119000 & 4.215084 & 38 \\
\hline & Economic growth rate, $g$ & 666 & 2.515130 & 3.271700 & -14.8141 & 25.11725 & 38 \\
\hline & Real interest rate, $r$ & 666 & 4.107304 & 5.319142 & -7.79727 & 93.91508 & 38 \\
\hline
\end{tabular}

macroeconomic controls, we consider overall government expenditure to control the redistributive influences of government spending. Despite the fact that it would be advisable to use social spending data, such disaggregated data are not easily accessed in the majority of developing countries. Thus, government spending is used as a proxy for social spending. Lustig et al. (2013) and Doerrenberg and Peichl (2014) stressed the significant role of government expenditure in affecting inequality in a group of Latin American and OECD countries, respectively. Furthermore, we control inflation since it is likely to have redistributive influences in society. Piketty (2014) points out that inflation reallocates income in favor of the higher income groups because their assets offer greater real returns. Albanesi (2007) suggests that higher inflation results in growing inequality, and the low-income families are affected more because of their greater tendency to hold cash. Therefore, it is advisable to control for inflation to compromise any 
Table 1 (continued)

\begin{tabular}{|c|c|c|c|c|c|c|c|}
\hline & Variable & Obs. & Mean & Std. Dev. & Min & Max & $\begin{array}{l}\text { No. } \\
\text { of countries }\end{array}$ \\
\hline \multirow{14}{*}{$\begin{array}{l}\text { Middle-income } \\
\text { countries }\end{array}$} & Net Gini & 677 & 0.425912 & 0.069817 & 0.263554 & 0.651835 & 38 \\
\hline & Economic freedom & 677 & 6.675165 & 0.590329 & 4.490000 & 8.130000 & 38 \\
\hline & $(r-g)$ & 677 & 2.391761 & 9.328471 & -19.6300 & 45.30657 & 38 \\
\hline & GDP/capita & 677 & 4637.375 & 3039.830 & 509.2934 & 14936.40 & 38 \\
\hline & $\begin{array}{l}\text { Govt. spending (as \% of } \\
\text { GDP) }\end{array}$ & 677 & 14.09789 & 4.550921 & 4.845660 & 26.24226 & 38 \\
\hline & Inflation & 677 & 6.805119 & 6.597990 & -1.71033 & 54.91537 & 38 \\
\hline & Population growth rate & 677 & 1.036393 & 1.105046 & -9.08063 & 7.786010 & 38 \\
\hline & $\begin{array}{l}\text { Natural resource rent (as \% } \\
\text { of GDP) }\end{array}$ & 677 & 4.235448 & 4.950148 & 0.090388 & 34.95626 & 38 \\
\hline & $\begin{array}{l}\text { Gross savings rate (as \% } \\
\text { of GDP) }\end{array}$ & 677 & 23.20267 & 9.285265 & 1.725070 & 52.27694 & 38 \\
\hline & Tax revenue (as \% of GDP) & 677 & 15.78482 & 5.461290 & 5.195323 & 33.70700 & 38 \\
\hline & Trade openness & 677 & 75.55680 & 35.85023 & 21.85226 & 220.4074 & 38 \\
\hline & Unemployment rate & 677 & 8.425778 & 6.424814 & 0.398000 & 33.47300 & 38 \\
\hline & Economic growth rate, $g$ & 677 & 4.354409 & 3.365922 & -14.7585 & 14.23139 & 38 \\
\hline & Real interest rate, $r$ & 677 & 6.746170 & 8.293964 & -18.1219 & 48.50473 & 38 \\
\hline \multirow{14}{*}{$\begin{array}{l}\text { Low-income } \\
\text { countries }\end{array}$} & Net Gini & 106 & 0.461624 & 0.042649 & 0.381994 & 0.555594 & 6 \\
\hline & Economic freedom & 106 & 6.903774 & 0.402226 & 5.670000 & 7.560000 & 6 \\
\hline & $(r-g)$ & 106 & 4.772507 & 8.815792 & -25.1359 & 31.17852 & 6 \\
\hline & GDP/capita & 106 & 768.3114 & 323.2740 & 341.8498 & 1635.491 & 6 \\
\hline & $\begin{array}{l}\text { Govt. spending (as \% of } \\
\text { GDP) }\end{array}$ & 106 & 12.25052 & 3.233796 & 7.105651 & 19.57000 & 6 \\
\hline & Inflation & 106 & 8.439280 & 5.272525 & -0.28750 & 26.23982 & 6 \\
\hline & Population growth rate & 106 & 2.934346 & 0.362304 & 1.578337 & 3.714288 & 6 \\
\hline & $\begin{array}{l}\text { Natural resource rent (as \% } \\
\text { of GDP) }\end{array}$ & 106 & 8.469635 & 5.226485 & 2.254186 & 22.09347 & 6 \\
\hline & $\begin{array}{l}\text { Gross savings rate (as \% } \\
\text { of GDP) }\end{array}$ & 106 & 19.58832 & 7.937639 & 4.664122 & 35.86171 & 6 \\
\hline & Tax revenue (as \% of GDP) & 106 & 12.87383 & 2.629814 & 8.089331 & 21.09405 & 6 \\
\hline & Trade openness & 106 & 51.83014 & 14.04451 & 23.98087 & 84.59729 & 6 \\
\hline & Unemployment rate & 106 & 6.232057 & 4.245522 & 0.699000 & 15.90000 & 6 \\
\hline & Economic growth rate, $g$ & 106 & 5.743697 & 2.766984 & -4.29512 & 13.19207 & 6 \\
\hline & Real interest rate, $r$ & 106 & 10.51620 & 8.028465 & -20.3470 & 30.23685 & 6 \\
\hline
\end{tabular}

Source Research calculations

bias it may leave on the impact of economic freedom on Gini coefficient. Furthermore, according to Fakir et al. (2017) and Graafland and Lous (2018) several macroeconomic standard variables such as gross savings rate, GDP per capita, trade openness, unemployment, population, natural resource rent, and tax revenue have been used as control variables. The main challenge in calculating the effect of economic freedom lies in its potential simultaneity with inequality; while economic freedom might worsen inequality in a country, as stated earlier, the initial levels of inequality might drive economic freedom. This endogeneity between economic freedom and inequality is aptly demonstrated by Ahmad (2017) and Clark and Lawson (2008). Hence, causality may also be directed 
from inequality to economic freedom. Rothstein and Uslaner (2005) account for this by emphasizing the way higher inequality allows the high-income groups to pass laws to themselves advantage, augmenting a lack of fairness; this discourages honesty in societies with more changes of economic freedom. Another explanation was presented by Alesina and Angeletos (2005), who noticed that greater inequality results in increased requests to redistribute regulation and taxes, allowing the policymaker to restrict economic freedom. They argue that the bi-directional connection between inequality and economic freedom can lead to unwavering persistence of them in a country through re-enforcing positive feedback. Such arguments are further empirically supported by Chong and Gradstein (2007), to whom the higher levels of inequality deteriorate the institutions exacerbating political stability, law enforcement, and battling corruption. Thus, the use of instrumental variables is required to lessen the possibility of endogeneity likely to biasing our results.

Our chosen instrument variables are Corruptions Perception Index (CPI), Democracy and Good Governance, which used the PCA (principal component analysis) method to obtain an overall score for good governance indicators. Considering that while Corruptions Perception Index (CPI) has been growingly adopted as an instrument to measure economic freedom, an extremely corrupt country is possible to experience higher inequality by construction (Fakir et al. 2017). But, Montinola and Jackman (2002) realized that government size, or in other words, less economic freedom does not aggravate corruption, opposing the view that larger governments entail more share of corruption. Likewise, Gupta et al. (2002) chose the length of exposure to democracy as their instrument. Nevertheless, greater exposure to democracy can inescapably result in highly sustainable institutions, granting more political power to the policy that allows for policies which lessen inequality directly. In this sense, the length of exposure to democracy also cannot ensure the exclusion restriction.

Accordingly, we employ good governance and democracy as indicators of the perceptions of the quality of government services (both public and civil) and the potential of the government to implement them regardless of political pressures. The extent to which government services are less effective and more bureaucratic, more individuals are motivated to participate in economic activities. In addition, government hurdles produce more opportunities for public agents to exert their influence to expropriate rents and other non-productive activities, whereas a lower perceived democracy and government effectiveness decrease the motivation of individuals to pay their fair share of tax, steering them toward more corrupt behavior and thus escalating inequality. Also, it can be argued that a more effective government and favorable governance will likely result in higher economic performance, which can affect income distribution.

We run Levin, Lin and Chu, Breitung, and Im, Pesaran and Shin's unit root tests in order to see if the variables in our data are stationary. Both the augmented Levin, Lin and Chu and Im, Pesaran and Shin, indicate that all variables are in fact stationary in level. Further, according to the Breitung test, all the variables are stationary in level (and these variables are also stationary with one-time difference) except for the variables of Gross savings rate, Government spending, trade openness, and population growth rate (Table 2). 
Table 2 Unit root result for global panel

\begin{tabular}{|c|c|c|c|c|c|c|}
\hline \multirow[t]{2}{*}{ Variable } & \multicolumn{2}{|c|}{ Levin, Lin and Chu } & \multicolumn{2}{|l|}{ Breitung } & \multicolumn{2}{|c|}{$\begin{array}{l}\text { Im, Pesaran } \\
\text { and Shin }\end{array}$} \\
\hline & Statistic & Prob. & Statistic & Prob. & Statistic & Prob. \\
\hline EFW & -6.75705 & 0.0000 & -5.15234 & 0.0000 & -4.57693 & 0.0000 \\
\hline$(r-g)$ & -11.0818 & 0.0000 & -7.81387 & 0.0000 & -9.42641 & 0.0000 \\
\hline Top $10 \%$ income share & -3.09485 & 0.0010 & -6.22224 & 0.0000 & -2.11443 & 0.0172 \\
\hline GDP/capita & -3.20408 & 0.0007 & -3.50304 & 0.0002 & -1.30504 & 0.0959 \\
\hline Govt. spending (as \% of GDP) & -3.83298 & 0.0001 & 0.89541 & 0.8147 & -1.30668 & 0.0957 \\
\hline Inflation & -13.0318 & 0.0000 & -4.25075 & 0.0000 & -8.44915 & 0.0000 \\
\hline Population growth rate & -6.92004 & 0.0000 & -1.24920 & 0.1058 & -9.87550 & 0.0000 \\
\hline Natural resource rent (as \% of GDP) & -4.95464 & 0.0000 & -3.60546 & 0.0002 & -2.41743 & 0.0078 \\
\hline Gross savings rate (as \% of GDP) & -6.57063 & 0.0000 & 1.22628 & 0.8900 & -5.50427 & 0.0000 \\
\hline Tax revenue (as \% of GDP) & -3.43201 & 0.0003 & -2.07706 & 0.0189 & -1.86406 & 0.0312 \\
\hline Trade openness & -3.21338 & 0.0007 & 0.46771 & 0.6800 & -2.30712 & 0.0105 \\
\hline Unemployment rate & -8.05644 & 0.0000 & -1.99774 & 0.0229 & -5.49416 & 0.0000 \\
\hline
\end{tabular}

Source Research calculations

\section{Empirical results}

\subsection{Inequality and economic freedom}

First, we report the results of the effects of economic freedom on inequality and then proceed with the $(r-g)$ specification. These are presented in columns (1) and (2) in Table 3. The order of presentation of the results moves from the OLS estimation to the IV 2SLS estimation. This initial regression is intended to differentiate the outcome of economic freedom on Gini as part of the institutional view of inequality. By controlling this, we are better able to test if $(r-g)$, which differs from the institutional view, as an internal mechanism of the capitalistic system proposed by Piketty (2014), exerts a real effect on Gini. This can also enable us to collate the effect size of economic freedom and $(r-g)$ on inequality, enabling to measure which one is likely to have a larger influence on inequality in the time period of the current research.

Whether fixed or random effects estimation is more suitable, the results of the Redundant fixed effects tests (F-Limer) and Correlated Random Effects Tests (Hausman test) show that all regressions should be estimated on the basis of Fixed Effects. As for the IV estimation given in column (2) in Table 3, the lag of Democracy and Good Governance and the square of CPI are employed as instruments for both EFW and EFW ${ }^{(2)}$.

As the Gini coefficient is an indicator of inequality, any decrease in the magnitude of the Gini coefficient signifies a leap towards greater economic equality. Economic freedom and economic freedom squared would be expected to initially have a positive and negative coefficient, respectively, as is the case with columns (1) and (2) in Table 3. Based on the non-IV specification reported in column (1), the increase of the economic freedom by 1 point will result in a 0.069 increase in the value of the Gini index, and inequality tends to decline at a turning point of $7.57 .{ }^{4}$ Nevertheless, despite the significant results, the size of the effect of economic freedom is rather small. Considering the

\footnotetext{
${ }^{4}$ Note that in this study, as in the case of Fakir et al. (2017), Tao et al. (2008), and Stern (2004), the turning point is obtained through the following relationship: $\mathrm{T}=\exp \left(-\mathrm{B}_{1} / 2 \mathrm{~B}_{2}\right)$.
} 
Table 3 Estimation results for global panel

\begin{tabular}{|c|c|c|c|c|c|c|}
\hline Variable & (1) EFW only & $\begin{array}{l}\text { (2) EFW } \\
\text { only [IV] }\end{array}$ & $\begin{array}{l}\text { (3) EFW } \\
\text { with }(r-g)\end{array}$ & $\begin{array}{l}\text { (4) EFW } \\
\text { with }(r-g) \\
\text { [IV] }\end{array}$ & $\begin{array}{l}\text { (5) EFW } \\
\text { with }(r-g) \times \text { EFW }\end{array}$ & $\begin{array}{l}\text { (6) EFW } \\
\text { with }(r-g) \times \text { EFW } \\
\text { [IV] }\end{array}$ \\
\hline EFW & $\begin{array}{r}0.069504^{* * * *} \\
(0.016147)\end{array}$ & $\begin{array}{r}0.451182^{* * * *} \\
(0.131949)\end{array}$ & $\begin{array}{r}0.069444^{* * * *} \\
(0.016154)\end{array}$ & $\begin{array}{r}0.455083^{* * * *} \\
(0.132865)\end{array}$ & $\begin{array}{r}0.069155^{* * * *} \\
(0.016126)\end{array}$ & $\begin{array}{r}0.458865^{* * * *} \\
(0.133532)\end{array}$ \\
\hline $\mathrm{EFW}^{2}$ & $\begin{array}{r}-0.00458^{* * *} \\
(0.001188)\end{array}$ & $\begin{array}{r}-0.03141^{* * *} \\
(0.009371)\end{array}$ & $\begin{array}{r}-0.00458^{* * *} \\
(0.001189)\end{array}$ & $\begin{array}{r}-0.03169^{* * * *} \\
(0.009437)\end{array}$ & $\begin{array}{c}-0.004534^{* * *} \\
(0.001187)\end{array}$ & $\begin{array}{r}-0.03188^{* * *} \\
(0.009479)\end{array}$ \\
\hline$(r-g)$ & & & $\begin{array}{l}1.71 E-05 \\
\quad(7.31 E-05)\end{array}$ & $\begin{array}{r}-4.09 E-05 \\
(8.94 E-05)\end{array}$ & $\begin{array}{l}0.001831^{* *} \\
(0.000766)\end{array}$ & $\begin{array}{r}0.002578^{* * *} \\
(0.000959)\end{array}$ \\
\hline$(r-g) \times E F W$ & & & & & $\begin{array}{c}-0.000260^{* *} \\
(0.000109)\end{array}$ & $\begin{array}{r}-0.00037^{* * *} \\
(0.000137)\end{array}$ \\
\hline $\begin{array}{l}\text { Lag GDP/ } \\
\text { capita }\end{array}$ & $\begin{array}{c}-7.39 \mathrm{E}-07^{* * *} \\
(2.45 \mathrm{E}-07)\end{array}$ & $\begin{array}{r}-9.69 \mathrm{E} 07^{* * *} \\
(3.34 \mathrm{E}-07)\end{array}$ & $\begin{array}{c}-7.43 \mathrm{E}-07^{* * *} \\
(2.46 \mathrm{E}-07)\end{array}$ & $\begin{array}{c}-9.59 \mathrm{E}-07^{* * *} \\
(3.36 \mathrm{E}-07)\end{array}$ & $\begin{array}{c}-7.10 \mathrm{E}-07^{* * *} \\
(2.46 \mathrm{E}-07)\end{array}$ & $\begin{array}{c}-9.04 \mathrm{E}-07^{* * *} \\
(3.36 \mathrm{E}-07)\end{array}$ \\
\hline $\begin{array}{l}\text { Govt. spend- } \\
\text { ing (as \% of } \\
\text { GDP) }\end{array}$ & $\begin{array}{c}-0.000646^{* *} \\
(0.000317)\end{array}$ & $\begin{array}{l}8.95 E-05 \\
(0.000461)\end{array}$ & $\begin{array}{c}-0.000651^{* *} \\
(0.000318)\end{array}$ & $\begin{array}{l}0.000108 \\
(0.000464)\end{array}$ & $\begin{array}{r}-0.000607^{*} \\
(0.000317)\end{array}$ & 0.0001900 .000470 \\
\hline Inflation & $\begin{array}{r}0.000315^{* * *} \\
(0.000116)\end{array}$ & $\begin{array}{r}0.001133^{* * *} \\
(0.000316)\end{array}$ & $\begin{array}{r}0.000318^{* * *} \\
(0.000116)\end{array}$ & $\begin{array}{r}0.001134^{* * *} \\
(0.000318)\end{array}$ & $\begin{array}{r}0.000346^{* * *} \\
(0.000117)\end{array}$ & $\begin{array}{r}0.001199^{* * *} \\
(0.000323)\end{array}$ \\
\hline $\begin{array}{l}\text { Population } \\
\text { growth rate }\end{array}$ & $\begin{array}{l}0.001014 \\
\quad(0.000905)\end{array}$ & $\begin{array}{l}0.000864 \\
\quad(0.001129)\end{array}$ & $\begin{array}{l}0.001005 \\
\quad(0.000906)\end{array}$ & $\begin{array}{l}0.000889 \\
\quad(0.001135)\end{array}$ & $0.000948(0.000905)$ & $0.000809(0.001140)$ \\
\hline $\begin{array}{l}\text { Natural } \\
\text { resource } \\
\text { rent (as \% of } \\
\text { GDP) }\end{array}$ & $\begin{array}{r}-0.000267 \\
(0.000251)\end{array}$ & $\begin{array}{r}-0.000732^{* *} \\
(0.000347)\end{array}$ & $\begin{array}{r}-0.000257 \\
0.000255\end{array}$ & $\begin{array}{c}-0.000762^{* *} \\
(0.000354)\end{array}$ & $\begin{array}{r}-0.000137 \\
(0.000259)\end{array}$ & $\begin{array}{r}-0.000597^{*} \\
(0.000356)\end{array}$ \\
\hline $\begin{array}{l}\text { Gross savings } \\
\text { rate (as \% of } \\
\text { GDP) }\end{array}$ & $\begin{array}{r}0.000413^{* * * *} \\
(0.000139)\end{array}$ & $\begin{array}{r}0.000681^{* * *} \\
(0.000192)\end{array}$ & $\begin{array}{r}0.000416^{* * *} \\
(0.000139)\end{array}$ & $\begin{array}{r}0.000677^{* * *} \\
(0.000192)\end{array}$ & $\begin{array}{r}0.000418^{* * *} \\
(0.000139)\end{array}$ & $\begin{array}{r}0.000685^{* * *} \\
(0.000193)\end{array}$ \\
\hline $\begin{array}{l}\text { Tax revenue } \\
\text { (as } \% \text { of } \\
\text { GDP) }\end{array}$ & $\begin{array}{r}-0.00115^{* * *} \\
(0.000158)\end{array}$ & $\begin{array}{r}-0.00193^{* * *} \\
(0.000268)\end{array}$ & $\begin{array}{r}-0.00115^{* * *} \\
(0.000158)\end{array}$ & $\begin{array}{r}-0.00194^{* * *} \\
(0.000269)\end{array}$ & $\begin{array}{c}-0.001139 * * * \\
(0.000158)\end{array}$ & $\begin{array}{r}-0.00192^{* * *} \\
(0.000270)\end{array}$ \\
\hline $\begin{array}{l}\text { Trade open- } \\
\text { ness }\end{array}$ & $\begin{array}{l}\text { 7.09E05** } \\
(3.49 E 05)\end{array}$ & $\begin{array}{l}9.63 E-05^{* *} \\
\quad(4.82 E-05)\end{array}$ & $\begin{array}{l}7.19 E-05^{* *} \\
\quad(3.52 E-05)\end{array}$ & $\begin{array}{l}9.38 E-05^{*} \\
\quad(4.87 E-05)\end{array}$ & $\begin{array}{l}6.62 E-05^{*} \\
\quad(3.52 E-05)\end{array}$ & $\begin{array}{l}8.30 E-05^{*} \\
\quad(4.92 E-05)\end{array}$ \\
\hline $\begin{array}{l}\text { Unemploy- } \\
\text { ment rate }\end{array}$ & $\begin{array}{r}0.001204^{* * *} \\
(0.000207)\end{array}$ & $\begin{array}{r}0.001002^{* * *} \\
(0.000278)\end{array}$ & $\begin{array}{r}0.001192^{* * *} \\
(0.000213)\end{array}$ & $\begin{array}{r}0.001028^{* * *} \\
(0.000284)\end{array}$ & $\begin{array}{r}0.001213^{* * *} \\
(0.000213)\end{array}$ & $\begin{array}{r}0.001076^{* * *} \\
(0.000285)\end{array}$ \\
\hline $\begin{array}{l}\text { Redundant } \\
\text { fixed effects } \\
\text { tests (prob) }\end{array}$ & $\begin{array}{c}208.474658 \\
(0.0000)\end{array}$ & & $\begin{array}{c}207.349682 \\
(0.0000)\end{array}$ & & $203.076909(0.0000)$ & \\
\hline Hausman test & $\begin{array}{r}69.065138 \\
(0.0000)\end{array}$ & & $\begin{array}{r}69.429193 \\
(0.0000)\end{array}$ & & $74.483952(0.0000)$ & \\
\hline Observations & 1394 & 1360 & 1394 & 1360 & 1394 & 1360 \\
\hline $\begin{array}{l}\text { Number of } \\
\text { countries }\end{array}$ & 82 & 80 & 82 & 80 & 82 & 80 \\
\hline Adj. R-squared & 0.970005 & 0.955503 & 0.969983 & 0.955181 & 0.970090 & 0.954825 \\
\hline F-statistic & 490.6446 & 485.0728 & 485.0167 & 479.4735 & 481.6390 & 476.5421 \\
\hline $\begin{array}{l}\text { Prob } \\
\qquad \text { (F-statistic) }\end{array}$ & 0.000000 & 0.000000 & 0.000000 & 0.000000 & 0.000000 & 0.000000 \\
\hline
\end{tabular}

Dependent variable is Gini of net income. All regressions report panel fixed effects. Standard errors are in parentheses and $* * * * * * *$ indicates significant at $1 \%, 5 \%$, and $10 \%$ level

Source Research calculations

existence of endogeneity, this outcome is likely due to substantial bias. With reverse causality that exists between inequality and economic freedom, an inconsequential result is not surprising. Employing our instruments, however, it can be seen that 2SLS estimation produces a significantly higher coefficient. This provides a better estimate since the IV treatment allows us to control for endogeneity.

Using IVs for the non-linear specification, presented in column (2), leads the coefficients on both terms to increase and stay significant. The outcomes of the IV model show that when the economic freedom score goes below 7.19, for a 1-point rise in the 
EFW, inequality is likely to continue to grow by 0.451 . Moreover, a country is clean enough so that inequality shrinks with increasing economic freedom. Likewise, a similar trend has been reported by Bennett and Vedder (2013) and Ahmad (2017), in which, despite using different variables (excluding $r-g$ ) and hence not directly comparable, an inverted U-shaped effect with the threshold is reported to lower inequality in their estimation standing roughly at 8.5 and 8.33 , respectively. Nevertheless, their estimation is hardly rigorous for every specification. Utilizing more contemporary data and a wide range of covariates, we obtain a turning point further down the line, which supports a pragmatic interpretation; it appears that a country growingly requires more economic freedom to facilitate reductions in inequality. As an illustration, for Bangladesh to cease to encounter increasing inequality stemming from economic freedom, Argentina (whose latest economic freedom score is 4.5 in 2017) would have to increase its level of economic freedom to reach that of Hungary (EFW score of 7.19 in 2015).

We can also speculate the reason why economic freedom might affect inequality with a non-linear pattern. With initially increasing economic freedom, the level of bureaucracy tends to decrease first. This suggests that businesses now find it far easier to operate without being subject to illegitimate rent-seeking behavior from the government agents and can raise the returns from business investment that result in rising inequality. However, beyond the EFW score of 7.19, higher levels of economic freedom that is, tax payment, large-scale bribe-taking, and government rent-seeking are likely to foster more just income redistribution. Therefore, it is secured that inequality can only decrease after a given threshold of economic freedom.

Table 4 presents the model estimation results for the three groups of high, middle, and low-income countries. The results are in agreement with the data presented in Table 3. According to the results, the variable of economic freedom has a more significant effect on inequality in both high and middle-income countries than the Piketty hypothesis. However, the effect of economic freedom on low-income countries' inequality is not significant, and the effect of $(r-g)$ is only significant at this level of $10 \%$ if using the instrument variable. Also the negative effect of economic freedom on inequality in highincome countries can confirm the non-linear relationship and the negative part of the curve inverse- $u$ with respect to the high degree of economic freedom in these countries.

Table 7 Appendix A fixed effects estimations and Table 8 IV estimations summarize the estimated results of the favored baseline specification to investigate if the various dimensions of economic freedom, $(r-g)$ and income inequality are correlated or not. Besides the variables of the baseline model, the effects of every single area of EFW, that is, EFW1 (government size), EFW2 (legal system and property rights), EFW3 (access to sound money), EFW4 (freedom to trade internationally), and EFW5 (regulation of credit, labor, and business) are also estimated.

\section{$5.2(r-g)$ hypothesis}

Note that Piketty's (2014) second fundamental law of capitalism was prescribed in the long run while we intended to test the relationship in the short run spanning 18 years. A study with an extended time period can prove to provide a desirable robustness check. 
Table 4 Estimation results for high-, middle-, and low-income countries

\begin{tabular}{|c|c|c|c|c|c|c|}
\hline \multirow[b]{2}{*}{ Variable } & \multicolumn{2}{|l|}{ High-income } & \multicolumn{2}{|l|}{ Middle-income } & \multicolumn{2}{|l|}{ Low-income } \\
\hline & $\begin{array}{l}\text { (1) EFW } \\
\text { with }(r-g) \times \\
\text { EFW }\end{array}$ & $\begin{array}{l}\text { (2) EFW } \\
\text { with }(r-g) \times \text { EFW } \\
\text { [IV] }\end{array}$ & $\begin{array}{l}\text { (3) EFW } \\
\text { with }(r-g) \times \text { EFW }\end{array}$ & $\begin{array}{l}\text { (4) EFW } \\
\text { with }(r-g) \times E F W \\
\text { [IV] }\end{array}$ & $\begin{array}{l}\text { (5) EFW } \\
\text { with }(r-g) \times \\
\text { EFW }\end{array}$ & $\begin{array}{l}\text { (6) EFW } \\
\text { with }(r-g) \times \text { EFW } \\
\text { [IV] }\end{array}$ \\
\hline EFW & $\begin{array}{l}0.012224 \\
(0.002944) * * *\end{array}$ & $\begin{array}{l}-0.027931 \\
(0.010880)^{* *}\end{array}$ & $\begin{array}{l}0.019469 \\
(0.002737)^{* * *}\end{array}$ & $\begin{array}{l}0.052680 \\
(0.009976)^{* * *}\end{array}$ & $\begin{array}{l}0.001709 \\
(0.006614)\end{array}$ & $\begin{array}{l}0.013558 \\
(0.021279)\end{array}$ \\
\hline$(r-g)$ & $\begin{array}{l}0.003302 \\
(0.001877)^{*}\end{array}$ & $\begin{array}{l}0.002655 \\
(0.002135)\end{array}$ & $\begin{array}{l}0.000704 \\
(0.001120)\end{array}$ & $\begin{array}{l}0.001298 \\
(0.001263)\end{array}$ & $\begin{array}{l}0.000546 \\
(0.004302)\end{array}$ & $\begin{array}{l}0.013752 \\
(0.006953)^{*}\end{array}$ \\
\hline$(r-g) \times E F W$ & $\begin{array}{c}-0.000477 \\
(0.000256)^{*}\end{array}$ & $\begin{array}{l}-0.000390 \\
(0.000292)\end{array}$ & $\begin{array}{l}-8.06 E-05 \\
0.000170\end{array}$ & $\begin{array}{l}-0.000160 \\
(0.000192)\end{array}$ & $\begin{array}{l}-6.13 E-05 \\
(0.000608)\end{array}$ & $\begin{array}{l}-0.001959 \\
(0.000983)^{* *}\end{array}$ \\
\hline $\begin{array}{l}\text { Lag GDP/ } \\
\text { capita }\end{array}$ & $\begin{array}{l}4.18 \mathrm{E}-07 \\
(2.41 \mathrm{E}-07)^{*}\end{array}$ & $\begin{array}{l}7.22 \mathrm{E}-07 \\
(2.67 \mathrm{E}-07)^{* * *}\end{array}$ & $\begin{array}{l}-7.29 \mathrm{E}-06 \\
(9.18 \mathrm{E}-07)^{* * *}\end{array}$ & $\begin{array}{l}-1.16 \mathrm{E}-05 \\
(1.59 \mathrm{E}-06)^{* * *}\end{array}$ & $\begin{array}{l}1.14 \mathrm{E}-05 \\
(1.74 \mathrm{E}-05)\end{array}$ & $\begin{array}{l}2.95 E-06 \\
(1.75 E-05)\end{array}$ \\
\hline $\begin{array}{l}\text { Govt. spend- } \\
\text { ing (as \% of } \\
\text { GDP) }\end{array}$ & $\begin{array}{l}-0.000525 \\
(0.000582)\end{array}$ & $\begin{array}{l}-0.002334 \\
(0.000746)^{* * *}\end{array}$ & $\begin{array}{l}-0.001207 \\
(-0.001207)^{* *}\end{array}$ & $\begin{array}{l}-0.000634 \\
(0.000572)\end{array}$ & $\begin{array}{l}0.001210 \\
(0.000803)\end{array}$ & $\begin{array}{l}0.001557 \\
(0.001285)\end{array}$ \\
\hline Inflation & $\begin{array}{l}0.000506 \\
(0.000298)^{*}\end{array}$ & $\begin{array}{l}-0.000126 \\
(0.000365)\end{array}$ & $\begin{array}{l}0.000294 \\
(0.000147)^{* *}\end{array}$ & $\begin{array}{l}0.000990 \\
(0.000258)^{* * *}\end{array}$ & $\begin{array}{l}0.000470 \\
(0.000355)\end{array}$ & $\begin{array}{l}-0.000498 \\
(0.000564)\end{array}$ \\
\hline $\begin{array}{l}\text { Population } \\
\text { growth rate }\end{array}$ & $\begin{array}{l}0.000792 \\
(0.001525)\end{array}$ & $\begin{array}{l}-0.000372 \\
(0.001698)\end{array}$ & $\begin{array}{l}0.000108 \\
(0.001176)\end{array}$ & $\begin{array}{l}-0.000533 \\
(0.001326)\end{array}$ & $\begin{array}{l}0.004484 \\
(0.007610)\end{array}$ & $\begin{array}{l}-0.045721 \\
(0.009437)^{* * *}\end{array}$ \\
\hline $\begin{array}{l}\text { Natural } \\
\text { resource } \\
\text { rent (as \% } \\
\text { of GDP) }\end{array}$ & $\begin{array}{c}-0.000932 \\
(0.000530)^{*}\end{array}$ & $\begin{array}{l}-0.000685 \\
(0.000563)\end{array}$ & $\begin{array}{l}-0.000742 \\
(0.000356)^{* *}\end{array}$ & $\begin{array}{l}-0.000906 \\
(0.000400)^{* *}\end{array}$ & $\begin{array}{l}0.000952 \\
(0.000609)\end{array}$ & $\begin{array}{l}0.000420 \\
(0.001036)\end{array}$ \\
\hline $\begin{array}{l}\text { Gross savings } \\
\text { rate (as \% of } \\
\text { GDP) }\end{array}$ & $\begin{array}{l}-0.000367 \\
(0.000245)\end{array}$ & $\begin{array}{l}-0.000644 \\
(0.000275)^{* *}\end{array}$ & $\begin{array}{l}0.000454 \\
(0.000191)^{* *}\end{array}$ & $\begin{array}{l}0.000429 \\
(0.000213)^{* *}\end{array}$ & $\begin{array}{l}0.001166 \\
(0.000476)^{* *}\end{array}$ & $\begin{array}{l}0.002799 \\
(0.000925)^{* *}\end{array}$ \\
\hline $\begin{array}{l}\text { Tax revenue } \\
\text { (as \% of } \\
\text { GDP) }\end{array}$ & $\begin{array}{l}-0.000691 \\
(0.000174)^{* * *}\end{array}$ & $\begin{array}{l}-0.001190 \\
(0.000229)^{* * *}\end{array}$ & $\begin{array}{l}-0.001305 \\
(0.000361)^{* * *}\end{array}$ & $\begin{array}{l}-0.001418 \\
(0.000404)^{* * *}\end{array}$ & $\begin{array}{l}-0.000904 \\
(0.001114)\end{array}$ & $\begin{array}{l}0.001325 \\
(0.002308)\end{array}$ \\
\hline $\begin{array}{l}\text { Trade open- } \\
\text { ness }\end{array}$ & $\begin{array}{l}-1.42 E-05 \\
(4.36 E-05)\end{array}$ & $\begin{array}{l}5.28 \mathrm{E}-05 \\
(4.94 \mathrm{E}-05)\end{array}$ & $\begin{array}{l}0.000126 \\
(6.61 \mathrm{E}-05)^{*}\end{array}$ & $\begin{array}{l}1.87 E-05 \\
(7.99 E-05)\end{array}$ & $\begin{array}{l}-0.000221 \\
(0.000176)\end{array}$ & $\begin{array}{l}0.000779 \\
(0.000250)^{* * *}\end{array}$ \\
\hline $\begin{array}{l}\text { Unemploy- } \\
\text { ment rate }\end{array}$ & $\begin{array}{l}0.001466 \\
(0.000252)^{* * *}\end{array}$ & $\begin{array}{l}0.000566 \\
(0.000376)\end{array}$ & $\begin{array}{l}0.001321 \\
(0.000430)^{* * *}\end{array}$ & $\begin{array}{l}0.000833 \\
(0.000500)^{*}\end{array}$ & $\begin{array}{l}-0.000569 \\
(0.001606)\end{array}$ & $\begin{array}{l}0.002975 \\
(0.001273)^{* *}\end{array}$ \\
\hline $\begin{array}{l}\text { Redundant } \\
\text { fixed effects } \\
\text { tests (prob) }\end{array}$ & $\begin{array}{l}125.551393 \\
(0.0000)\end{array}$ & & $\begin{array}{l}211.849998 \\
(0.0000)\end{array}$ & & $\begin{array}{l}31.495902 \\
(0.0000)\end{array}$ & \\
\hline $\begin{array}{l}\text { Hausman test } \\
\text { (Prob) }\end{array}$ & $\begin{array}{l}51.324853 \\
(0.0000)\end{array}$ & & $\begin{array}{l}24.774029 \\
(0.0159)\end{array}$ & & - & \\
\hline Observations & 646 & 629 & 646 & 646 & 102 & 102 \\
\hline $\begin{array}{l}\text { Number of } \\
\text { countries }\end{array}$ & 38 & 37 & 38 & 38 & 6 & 6 \\
\hline Adj. R-squared & 0.949992 & 0.944860 & 0.945949 & 0.932593 & 0.912050 & 0.738918 \\
\hline F-statistic & 251.0613 & 269.7732 & 231.3719 & 225.0688 & 62.61075 & 27.29917 \\
\hline $\begin{array}{l}\text { Prob } \\
\qquad \text { (F-statistic) }\end{array}$ & 0.000000 & 0.000000 & 0.000000 & 0.000000 & 0.000000 & 0.000000 \\
\hline
\end{tabular}

Dependent variable is Gini of net income. All regressions report panel fixed effects. Standard errors are in parentheses and $* *^{* * *},{ }^{*}$ indicates significant at $1 \%, 5 \%$, and $10 \%$ level

Source Research calculations

The main constraint threatening this is whether data will be available over such a long time period, particularly in developing countries.

However, one can gain valuable insights from this exercise. Acemoglu and Robinson (2015) reported that the $(r-g)$ hypothesis is such a weak explanatory variable for the stable increase in inequality over the previous century. Institutions tend to remain rather stable in the short term and only come to evolve in the long run. Therefore, 
through concentrating on the short run, the role of institutional changes in creating inequality can be minimized; the attention can be shifted more to the causal relationship between inequality and $(r-g)$. Results are presented in Table 3: columns (3) and (4) provide $(r-g)$ in the presence of EFW and EFW ${ }^{2}$ and columns (5) and (6) capture the interaction between $(r-g)$ and EFW building upon the prior specification.

Like the non-linear IV specification given in column (2), we utilize the lag of democracy and good governance, and the square of CPI as instruments for both EFW and $\mathrm{EFW}^{2}$ for the IV model with $(r-g)$ only in column (4). For the specification that contains the interaction of $(r-g)$ and EFW presented in column (6), besides employing the two earlier instruments, we also use the interaction between $(r-g)$ and democracy for instrumenting $(r-g) \times$ EFW, as proposed by Cameron and Trivedi (2009).

Expectedly, economic freedom tends to remain significant, manifesting a non-linear effect on inequality. Economic freedom, as well as its squared term, even demonstrates approximately consistent turning points in each specification. We noticed that $(r-g)$ is an important predictor of inequality if the interactive effects in the specifications are regarded as economic freedom, even after the non-linear effects of economic freedom are controlling for. However, the effect size of $(r-g)$ is relatively small compared to those of EFW, although they are greater than the magnitude of the effects of such variables as savings, Inflation, Unemployment rate, and Trade openness. This signifies that even though $(\mathrm{r}-\mathrm{g})$ has a considerable influence, it is far from being the principal determinant of inequality.

It should be noted that during low levels of preexisting economic freedom, economic freedom increases inequality far beyond $(r-g)$, almost like positive feedback. This indicates that institutional failures should be blamed more than the dynamics of capitalism itself. Moreover, $(r-g)$ ceases to be significant for developing countries (although both EFW and EFW ${ }^{2}$ do not lose their significance) when segregated regressions are run for the developing and developed countries, probably thanks to shrinking financial and/or capital markets since the influence of $(\mathrm{r}-\mathrm{g})$ on inequality is mostly mediated by these markets' rate of growth. Hence, although Piketty's theory offers an empirical advantage, our discoveries indicate that the institutional analysis provided by Acemoglu and Robinson (2015) is more robust even in a short time frame.

Also, we examine the interaction between economic freedom and $(r-g)$. Assuming that the EFW scores represent economic freedom, they reflect the efficacy of institutions in a nation over a certain time period. The interaction term enables us to take into account a given level of economic freedom, whether or not $(r-g)$ has a greater effect on the level of inequality.

In addition to the inclusion of the interaction term that helps raising the degree and standard error of both economic freedom and $(r-g)$, the interaction term itself is negatively significant. Differentiation in terms of $(r-g)$ demonstrates that $(r-g)$ causes inequality to rise for relatively low levels of EFW, implying that we can provide evidence as to the varying effects of $(r-g)$ on inequality for various values of 
EFW. Once more, this is an indication that ineffective institutional systems bear a greater responsibility for inequality than the $(r-g)$ phenomenon, at least in our time frame. The findings of the present study suggest that even if the rate of returns is higher than growth rates, institutional failures to maintain economic freedom provide a far better account of the levels of inequality (Table 4).

\subsection{Results of the top $10 \%$ income share}

In the present study, the dependent variable measured our adopting of the standardized Gini coefficients. Gini coefficients provide an absolutely synthetic estimate of inequality. This means that they fail to examine the structural causes of evolution of inequality over time. In this regard, Gini coefficients are not a strong measure. But, considering the fact that no top $10 \%$ income shares have been consistently reported for a large number of countries in our panel, the use of Gini coefficients produces maximum possible comparability and coverage. Nonetheless, to provide a richer picture, we test the results employing the data on $10 \%$ income share for a relatively smaller set of nations. The results are provided in Table 5.

It was observed that economic freedom is still the dominant predictor of inequality. However, the non-linear association now differs from that of the Gini coefficient model. It was also found that in IV specification, there exists a significant non-linear relationship between $10 \%$ income shares and economic freedom, only taking endogeneity into account. This indicates that upon an increase in the level of economic freedom, inequality initially starts to increase. Beyond the EFW scores of 7.06, the top $10 \%$ income share starts to decrease. This provides stark validity evidence in support of the results derived when Gini coefficients are employed, similarly indicating the effects of economic freedom on top $10 \%$ income shares than the overall inequality. A possible justification is that with the increase of economic freedom, those individuals who make up the top 10\% income shares are likely to better benefit from the capital markets' proper functioning to have higher returns.

If top $10 \%$ income shares are used, similar to the time when the Gini coefficient is used, $(r-g)$ can only be significant when interactive effects are used in conjunction with economic freedom. This finding is somehow compatible with those of Acemoglu and Robinson (2015), who reported that $(r-g)$ cannot considerably account for the variations in the top $10 \%$ income shares. Nevertheless, considering the observation that $(r-g)$ aggravates inequality when the Gini coefficient is utilized, this offers appealing consequences. One possible reason suggested by Acemoglu and Robinson (2015) concerns the endogenous technological and institutional changes explaining the rise in inequality observed today. Alternatively, it may stem from the fact that $(r-g)$ fails to considerably raise the top $10 \%$ income shares over a short period of time, but it debilitates inequality by causing the income to go to other social groups to rise. 
Table 5 Estimation results of top $10 \%$ income share

\begin{tabular}{|c|c|c|c|c|c|c|}
\hline Variable & $\begin{array}{l}\text { (1) } \\
\text { EFW only }\end{array}$ & $\begin{array}{l}\text { (2) } \\
\text { EFW only [IV] }\end{array}$ & $\begin{array}{l}\text { (3) } \\
\text { EFW } \\
\text { with }(r-g)\end{array}$ & $\begin{array}{l}(4) \\
\text { EFW } \\
\text { with }(r-g) \\
{[I V]}\end{array}$ & $\begin{array}{l}(5) \\
\text { EFW with } \\
(r-g) \times E F W\end{array}$ & $\begin{array}{l}(6) \\
\text { EFW with } \\
(r-g) \times E F W \\
{[I V]}\end{array}$ \\
\hline EFW & $\begin{array}{l}0.013737 \\
(0.030120)\end{array}$ & $\begin{array}{l}0.399004^{* *} \\
(0.182726)\end{array}$ & $\begin{array}{l}0.006852 \\
(0.029882)\end{array}$ & $\begin{array}{l}0.353396^{*} \\
(0.182090)\end{array}$ & $\begin{array}{l}0.011399 \\
(0.029729)\end{array}$ & $\begin{array}{l}0.327382^{*} \\
(0.176825)\end{array}$ \\
\hline $\mathrm{EFW}^{2}$ & $\begin{array}{l}-3.69 E-05 \\
(0.002140)\end{array}$ & $\begin{array}{l}-0.028272^{* *} \\
(0.013159)\end{array}$ & $\begin{array}{l}0.000454 \\
(0.002123)\end{array}$ & $\begin{array}{l}-0.024912^{*} \\
(0.013119)\end{array}$ & $\begin{array}{l}0.000195 \\
(0.002111)\end{array}$ & $\begin{array}{l}-0.022946^{*} \\
(0.012732)\end{array}$ \\
\hline$(r-g)$ & & & $\begin{array}{l}-0.000535 \\
(0.002134)\end{array}$ & $\begin{array}{l}-0.000427 \\
(0.001150)\end{array}$ & $\begin{array}{l}0.003297^{* * *} \\
(0.001181)\end{array}$ & $\begin{array}{l}0.004277^{* * *} \\
(0.001318)\end{array}$ \\
\hline$(r-g) \times E F W$ & & & & & $\begin{array}{l}-0.000542^{* * *} \\
(0.000166)\end{array}$ & $\begin{array}{l}-0.000668^{* * *} \\
(0.000184)\end{array}$ \\
\hline $\begin{array}{l}\text { Lag GDP/ } \\
\text { capita }\end{array}$ & $\begin{array}{l}1.19 \mathrm{E}-06^{* * *} \\
(3.09 \mathrm{E}-07)\end{array}$ & $\begin{array}{l}1.08 \mathrm{E}-06^{* * *} \\
(3.81 \mathrm{E}-07)\end{array}$ & $\begin{array}{l}1.38 E-06^{* * *} \\
(3.10 E-07)\end{array}$ & $\begin{array}{l}1.26 \mathrm{E}-06^{* * *} \\
(3.82 \mathrm{E}-07)\end{array}$ & $\begin{array}{l}1.43 \mathrm{E}-06^{* * *} \\
(3.08 \mathrm{E}-07)\end{array}$ & $\begin{array}{l}1.38 \mathrm{E}-06^{* * *} \\
3.72 \mathrm{E}-07\end{array}$ \\
\hline $\begin{array}{l}\text { Govt. spend- } \\
\text { ing (as \% of } \\
\text { GDP) }\end{array}$ & $\begin{array}{l}-0.000526 \\
(0.000624)\end{array}$ & $\begin{array}{l}-0.002712^{* *} \\
(0.001103)\end{array}$ & $\begin{array}{l}2.91 E-05 \\
(0.000633)\end{array}$ & $\begin{array}{l}-0.002040^{*} \\
(0.001133)\end{array}$ & $\begin{array}{l}0.000103 \\
(0.000629)\end{array}$ & $\begin{array}{l}-0.001786 \\
(0.001097)\end{array}$ \\
\hline Inflation & $\begin{array}{l}0.0009^{* * *} \\
(0.000216)\end{array}$ & $\begin{array}{l}0.00141^{* * *} \\
(0.000413)\end{array}$ & $\begin{array}{l}0.00083^{* * *} \\
(0.000214)\end{array}$ & $\begin{array}{l}0.001318^{* * *} \\
(0.000411)\end{array}$ & $\begin{array}{l}0.000927^{* * *} \\
(0.000215)\end{array}$ & $\begin{array}{l}0.001384^{* * *} \\
(0.000408)\end{array}$ \\
\hline $\begin{array}{l}\text { Population } \\
\text { growth rate }\end{array}$ & $\begin{array}{l}8.91 E-05 \\
(0.001663)\end{array}$ & $\begin{array}{l}-0.003308 \\
(0.001939)\end{array}$ & $\begin{array}{l}0.000336 \\
(0.001648)\end{array}$ & $\begin{array}{l}-0.002915 \\
(0.001900)\end{array}$ & $\begin{array}{l}0.000207 \\
(0.001639)\end{array}$ & $\begin{array}{l}-0.002964 \\
(0.001864)\end{array}$ \\
\hline $\begin{array}{l}\text { Natural } \\
\text { resource } \\
\text { rent (as \% } \\
\text { of GDP) }\end{array}$ & $\begin{array}{l}0.0014^{* * *} \\
(0.000414)\end{array}$ & $\begin{array}{l}0.001128^{* *} \\
(0.000496)\end{array}$ & $\begin{array}{l}0.00119^{* * *} \\
(0.000414)\end{array}$ & $\begin{array}{l}0.000972^{* *} \\
(0.000482)\end{array}$ & $\begin{array}{l}0.001538^{* * *} \\
(0.000425)\end{array}$ & $\begin{array}{l}0.001424^{* * *} \\
(0.000473)\end{array}$ \\
\hline $\begin{array}{l}\text { Gross savings } \\
\text { rate (as \% of } \\
\text { GDP) }\end{array}$ & $\begin{array}{l}0.0008^{* * *} \\
(0.000247)\end{array}$ & $\begin{array}{l}0.000370 \\
(0.000297)\end{array}$ & $\begin{array}{l}0.00082^{* * * *} \\
(0.000245)\end{array}$ & $\begin{array}{l}0.000383 \\
(0.000290)\end{array}$ & $\begin{array}{l}0.000841^{* * *} \\
(0.000243)\end{array}$ & $\begin{array}{l}0.000411 \\
(0.000284)\end{array}$ \\
\hline $\begin{array}{l}\text { Tax revenue } \\
\text { (as \% of } \\
\text { GDP) }\end{array}$ & $\begin{array}{l}-0.0011^{* * *} \\
(0.000219)\end{array}$ & $\begin{array}{l}-0.00107^{* * *} \\
(0.000379)\end{array}$ & $\begin{array}{l}-0.0011^{* * *} \\
(0.000217)\end{array}$ & $\begin{array}{c}-0.001097^{* * *} \\
(0.000370)\end{array}$ & $\begin{array}{l}-0.001142^{* * *} \\
(0.000216)\end{array}$ & $\begin{array}{l}-0.001137^{* * *} \\
(0.000363)\end{array}$ \\
\hline $\begin{array}{l}\text { Trade open- } \\
\text { ness }\end{array}$ & $\begin{array}{l}0.0001^{* * *} \\
(5.15 \mathrm{E}-05)\end{array}$ & $\begin{array}{l}0.00017^{* * *} \\
(6.34 \mathrm{E}-05)\end{array}$ & $\begin{array}{l}0.000113^{* *} \\
(5.15 \mathrm{E}-05)\end{array}$ & $\begin{array}{l}0.000152^{* *} \\
(6.26 \mathrm{E}-05)\end{array}$ & $\begin{array}{l}0.000100^{*} \\
5.13 \mathrm{E}-05\end{array}$ & $\begin{array}{l}0.000134^{* *} \\
(6.13 E-05)\end{array}$ \\
\hline $\begin{array}{l}\text { Unemploy- } \\
\text { ment rate }\end{array}$ & $\begin{array}{l}0.0009^{* * *} \\
(0.000297)\end{array}$ & $\begin{array}{l}0.000545 \\
(0.000347)\end{array}$ & $\begin{array}{l}0.00119^{* * * *} \\
(0.000301)\end{array}$ & $\begin{array}{l}0.000799^{* *} \\
(0.000349)\end{array}$ & $\begin{array}{l}0.001258^{* * *} \\
(0.000300)\end{array}$ & $\begin{array}{l}0.000910^{* * *} \\
(0.000342)\end{array}$ \\
\hline $\begin{array}{l}\text { Redundant } \\
\text { fixed effects } \\
\text { tests (prob) }\end{array}$ & $\begin{array}{c}191.149234 \\
(0.0000)\end{array}$ & & $\begin{array}{c}192.287047 \\
(0.0000)\end{array}$ & & $\begin{array}{c}182.896032 \\
(0.0000)\end{array}$ & \\
\hline Hausman test & $\begin{array}{r}76.370610 \\
(0.0000)\end{array}$ & & $\begin{array}{r}83.877975 \\
(0.0000)\end{array}$ & & $\begin{array}{r}95.063515 \\
(0.0000)\end{array}$ & \\
\hline Observations & 833 & 799 & 833 & 799 & 833 & 799 \\
\hline $\begin{array}{l}\text { Number of } \\
\text { countries }\end{array}$ & 49 & 47 & 49 & 47 & 49 & 47 \\
\hline Adj. R-squared & 0.964721 & 0.959210 & 0.965393 & 0.961163 & 0.965821 & 0.962650 \\
\hline F-statistic & 386.6131 & 392.0626 & 387.8205 & 392.4591 & 386.4177 & 391.3175 \\
\hline $\begin{array}{l}\text { Prob(F-sta- } \\
\text { tistic) }\end{array}$ & 0.000000 & 0.000000 & 0.000000 & 0.000000 & 0.000000 & 0.000000 \\
\hline
\end{tabular}

Dependent variable is the top $10 \%$ income share. All regressions report panel fixed effects. Standard errors are reported in parentheses and ${ }^{* * *}, * * *$, , respectively, means significant at $1 \%, 5 \%$, and $10 \%$ level

Source Research calculations

\subsection{Quantile regressions}

After demonstrating the existence of a basic relationship between economic freedom, $(r-g)$, and inequality, it would be interesting to further examine the variations of effects 


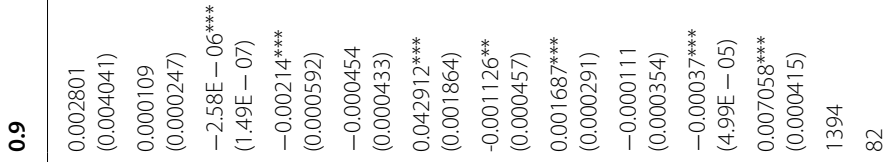

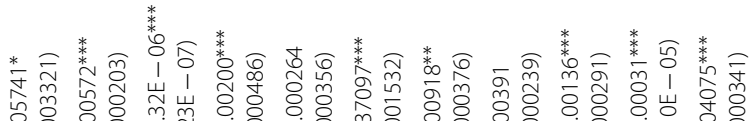

œ

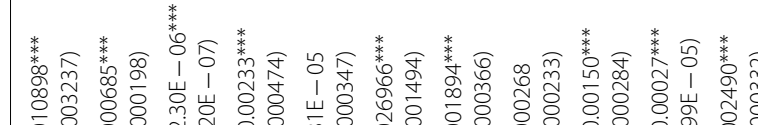

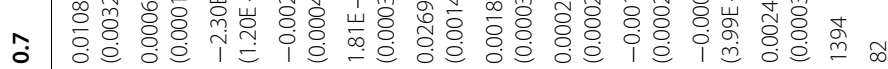

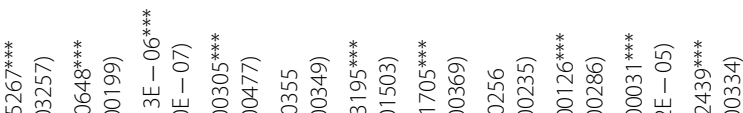

○.

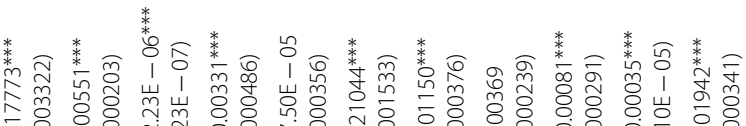

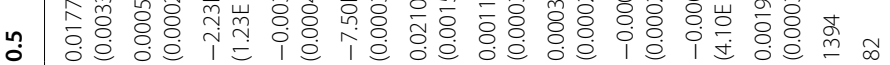

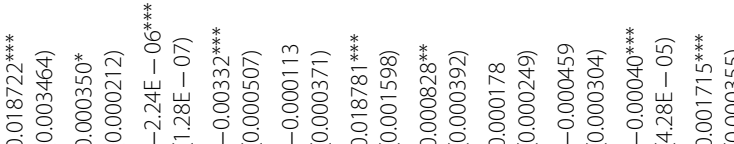

ナ.

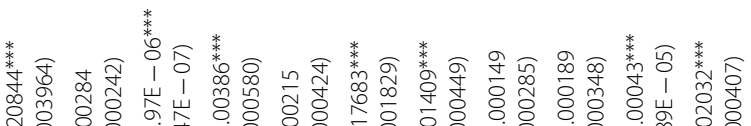

m

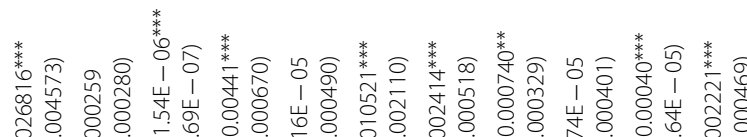

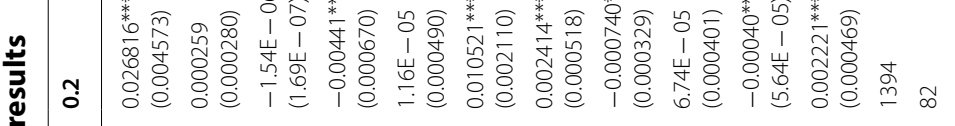

类

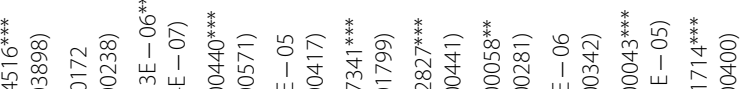

-

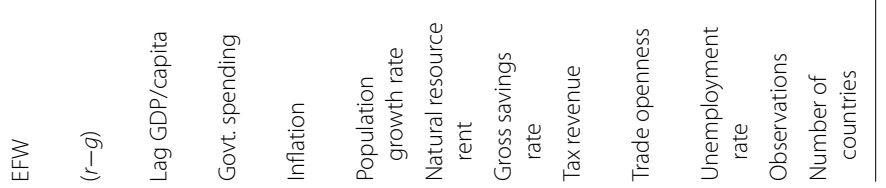




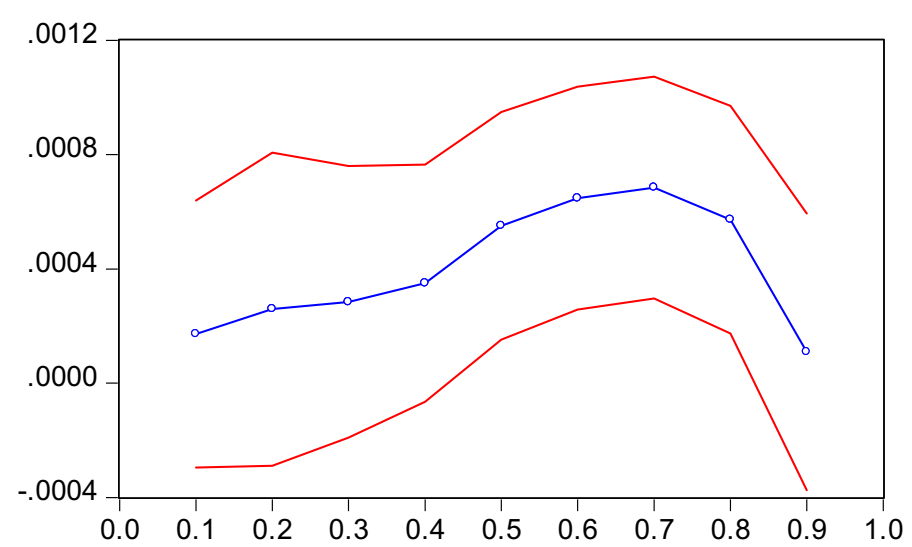

Fig. 2 Quantile estimations of $(r-g)$ on inequality

with levels of inequality. Quantile regressions were used in this study to further explore the variations in the effects of economic freedom and $(r-g)$ on levels of inequality. Upon the establishment of a non-linear relationship between economic freedom and inequality and showing that inequality for virtually every level of economic freedom is increased by $(r-g)$, now the existence of linear relationships between the variables and inequality is investigated. The results can be found in Table 6.

Excluding the 80th quantile, it seems that the outcomes of economic freedom reduce with higher levels of inequality. This indicates that economic freedom affects the top 10\% income less than expected while looking at Gini based "broader inequality". The implication is that in already highly unequal societies, as compared with more egalitarian nations, rises in the scores of economic freedom debilitate inequality to a smaller extent, or conversely, further economic freedom produces lower inequality. In accurate terms, for a country that falls in the 80th quantile of inequality, the rise of economic freedom score by one unit is likely to raise inequality by 0.0057 in comparison with a rise of inequality by 0.0245 for a country that is in the 10th quantile. Given the other covariates, in countries that are highly unequal, that is, countries in higher quantiles, it could be observed that greater extents of population growth and high levels of unemployment have a far larger effect on the rise of inequality than economic freedom, in comparison with that of the countries that are more equal, that is, the ones in lower quantiles). In countries that are more equal, in which these factors tend to have a lower impact, greater effects can be observed for an increase in economic freedom.

In addition, a manifest rising trend of $(r-g)$ can be seen with ascending quantiles of inequality. At the 40th quantile, $(r-g)$ is significant with a coefficient of 0.00035 while it grows to 0.000685 as we proceed to the 70th quantile. This indicates that at high degrees of inequality, $(r-g)$ tends to have a larger impact on inequality. It should not be noted that in developing countries (average net Gini of 42.2), where there exist larger average net values of Gini compared to those of the developed countries (average net Gini value of 29.9), this generates the expected observed relationship. 
Figure 2 demonstrates a clear ascending influence of $(r-g)$ on inequality. Although there are some irregularities along the quantiles, this provides us with a deeper view than an OLS average. This indicates that in highly unequal societies, pure capitalist dynamics also have a dominant role besides institutional factors.

\section{Discussion}

As can be observed from the results of quantile regressions, economic freedom continues to powerfully explain the variations in inequality even at its high levels, while its effects are primarily stronger. As the incidence of little economic freedom can be an indication of the institutional dysfunction, both conclusions can be viewed as being mutually reinforcing. One possible explanation in support of this is that, as far as inequality is concerned, the returns to capital are not straightforward. This can strengthen the hypothesis that levying high taxes on capital returns is not required. Conversely, we noticed that at middle ranges of inequality, $(r-g)$ does significantly contribute to inequality. Consequently, as long as $r$ is greater than $g$, the capital owners accumulate higher incomes than the other members of the society, which can be re-invested to produce more capital. Such a short-term dynamic can fuel considerable long-term wealth inequality when capital concentration augments in the hands of the initial capital owners. Piketty (2015) illustrated this by displaying that capital owners can raise their hold on it as a result of reinvesting $g / r$ of their income. Thus, in similar cases, policies must be formulated to redistribute the income derived from capital. But in all cases, the coefficient of economic freedom is greater than $(r-g)$. Also, given that the interactive effect of $(r-g)$ with economic freedom is negative, strengthening institutional factors will reduce the effects of $(r-g)$ on inequality.

In fact, this observation is striking and apparently supported by theoretical predictions. Needless to say that liberalization policies demand sufficient political support as long as the existence of economic motives and institutions is consistently decided by the political authorities and the executive constraints in the country. As demonstrated by Acemoglu et al. (2005), a country's economic development is a function of economic institutions, and economic institutions, in turn, are established to maintain the political interests of the ruling system. The existence of economic freedom along with other institutional factors allows coherent and effective labor unions with plenty of negotiating power to demand higher bottom lines, less skill-based and technologically driven wage bottom lines, etc. In a nutshell, it is expected that a democratic system has the power to facilitate income distribution and offset freedom-induced inequality.

Nevertheless, greater taxes on capital are always politically very difficult to implement because of different factors. In contrast, it could be simpler to approach a political agreement to improve the quality of institutions. Despite the existence of political agreement to enhance the quality of institutions, attempts have largely been futile in most developing countries. In our panel, the great proportion of developing countries displayed only a little growth in their EFW scores, or even dropped in it. As an illustration, Argentina 
reported lowered scores from 7.34 to 4.84 between 2000 and 2016. The failure to see any drastic changes in EFW in most developing countries demonstrates the status of the embedded institutions.

Such a slow improvement does often stem from a static lawmaking system dominated by the interested policymakers. This stickiness of laws can be explained by the institutionally shaped psyche and culture of some countries. Thus, in spite of the legislative changes, no real institutional change is discerned in some countries. Furthermore, vested interests may hamper the equitable functioning of the legal systems and efficient watchdogs. An assortment of these factors accounts for the reason why economic freedom remains a challenge to be addressed in many countries. Considering that economic freedom can mitigate inequality, this can be a wasted opportunity for developing countries to tap in order to undermine the foundations of a totalitarian society.

\section{Conclusion and policy implications}

Mixed discoveries in the past investigations either on the go-togetherness of economic freedom-inequality or $(r-g)$-inequality have failed to offer policymakers, development agencies, and other stakeholders sufficient information on the potential distributive outcomes of liberalization policies a country undertakes. For this purpose, an inequality model overtly capturing the interaction influence of economic freedom and $(r-g)$ was estimated to measure the distributive effect of $(r-g)$, and this outcome was assumed to vary in conjunction with economic liberalization policy. This study employed the most recent inequality data derived from SWIID version 9.0 and World Inequality Database (WID), which is unique on various grounds, e.g., in allowing for far superior comparability and reliability than the other inequality datasets, for around 82 countries over 18 years.

We noticed that economic freedom is the engine of inequality in every specification used in this study. More specifically, by investigating the non-linear impacts of EFW on Gini, we managed to specify a clear-cut threshold at which economic freedom no longer leads to growing inequality. At EFW scores beyond 7.19, the growth of economic freedom leads to a decrease in inequality. This indicates that facilitation of economic freedom should be a common concern of policymakers struggling with rising inequality. Nevertheless, at present, the majority of developing countries have lower EFW scores than those left with little ability for bringing about enhancements in the same scale in the short run. In contrast, although $(r-g)$ was found to be significant in most of the specifications in this study, its effect size on inequality remained relatively small. Nevertheless, these effects could be augmented in the long run to facilitate remarkable increases in inequality, in case they are left intact. Note that no evidence was found regarding the effect of $(r-g)$ in extremely unequal societies, therefore, it can be concluded that in such situations, the role of institutional 
factors is dominant. According to the available evidence, it seems that institutional quality is the most vital determinant of inequality over a short period of time.

Since economic freedom and the efficacy of institutions were highly correlated, promotion of economic freedom can be a crucial policy measure that must be adopted inordinately by policymakers who aim to eradicate inequality. In comparison with economic freedom, $(r-g)$ variable also has a positive correlation with inequality, although caution should be exercised for this interpretation, given the level of economic freedom. However, the results are indicative of a negative but statistically significant interaction effect of economic freedom- $(r-g)$, demonstrating that the $(r-g)$-induced inequality is lower in the presence of economic freedom. In summary, this research was successful in fulfilling its overarching goal to reveal the distinguished inequality-effect of $(r-g)$ with institutional factors.

Such a finding is of utmost importance for policymakers who are to make informed decisions on the enhancement of institutional quality measures. This demands that the free market reform policy be embedded after registering a special level due to the distinct ad significant redistributive effect when the similar policy reform is implemented in the countries that are at other levels of economic freedom. In this context, the findings of the current study suggest that improving institutional quality holds a potential to maintain and distribute the advantages of such market reforms across a wider segment of the population through different egalitarian redistributive measures such as welfare-enhancing transfers, more accessible education, and other income-equalizing measure. Also, a good governance is supposed to have a high level of transparency and accountability in the implementation of reform policies eradicating the possible rent-seeking traditions and seeking interests from the wealthy portion of the population.

Acknowledgements

We wish to thank the University of Isfahan and Social Security Research Institute.

Authors' contributions

AS data analysis and writing, KN conceptualizing the idea, KA conceptualizing the idea, RBD conceptualizing the idea. All authors read and approved the final manuscript.

Funding

This study received no funding.

Availability of data and materials

The data provided by this study along with the material are available.

Competing interests

There is none.

\section{Appendix A}

See Tables 7 and 8. 
Table 7 Fixed effect estimation results of five areas of economic freedom

\begin{tabular}{|c|c|c|c|c|c|}
\hline Variable & (1) & (2) & (3) & (4) & (5) \\
\hline$(r-g)$ & $\begin{array}{l}-6.20 E-05 \\
(0.000435)\end{array}$ & $\begin{array}{l}0.001295^{* * *} \\
(0.000337)\end{array}$ & $0.000874 *(0.000475)$ & $\begin{array}{l}-0.000311 \\
(0.000606)\end{array}$ & $\begin{array}{l}0.001607^{* * *} \\
(0.000459)\end{array}$ \\
\hline Lag GDP/capita & $\begin{array}{l}-7.19 \mathrm{E}-07^{* * *} \\
(1.78 \mathrm{E}-07)\end{array}$ & $\begin{array}{l}-6.60 \mathrm{E}-07^{* * *} \\
(2.51 \mathrm{E}-07)\end{array}$ & $\begin{array}{l}-6.93 \mathrm{E}-07^{* * *} \\
(2.49 \mathrm{E}-07)\end{array}$ & $\begin{array}{l}-8.62 \mathrm{E}-07^{* * *} \\
(2.62 \mathrm{E}-07)\end{array}$ & $\begin{array}{l}-7.92 \mathrm{E}-07^{* * *} \\
(2.61 \mathrm{E}-07)\end{array}$ \\
\hline $\begin{array}{l}\text { Govt. spending (as \% } \\
\text { of GDP) }\end{array}$ & $\begin{array}{l}-0.000504^{*} \\
(0.000281)\end{array}$ & $\begin{array}{l}-0.000717^{* *} \\
(0.000321)\end{array}$ & $\begin{array}{l}-0.00093^{* * *} \\
(0.000318)\end{array}$ & $\begin{array}{l}-0.000785^{* *} \\
(0.000316)\end{array}$ & $\begin{array}{l}-0.000770^{* *} \\
(0.000318)\end{array}$ \\
\hline Inflation & $\begin{array}{l}5.08 \mathrm{E}-05 \\
(0.000116)\end{array}$ & $\begin{array}{l}0.000145 \\
(0.000109)\end{array}$ & $\begin{array}{l}9.46 E-05 \\
(0.000133)\end{array}$ & $\begin{array}{l}0.000123 \\
(0.000110)\end{array}$ & $\begin{array}{l}0.000126 \\
(0.000110)\end{array}$ \\
\hline Population growth rate & $\begin{array}{l}0.000660 \\
(0.001667)\end{array}$ & $\begin{array}{l}0.001019 \\
(0.000909)\end{array}$ & $\begin{array}{l}0.001093 \\
(0.000913)\end{array}$ & $\begin{array}{l}0.001196 \\
(0.000909)\end{array}$ & $\begin{array}{l}0.000999 \\
(0.000913)\end{array}$ \\
\hline $\begin{array}{l}\text { Natural resource rent } \\
\text { (as \% of GDP) }\end{array}$ & $\begin{array}{l}-0.000245 \\
(0.000273)\end{array}$ & $\begin{array}{l}-5.69 E-05 \\
(0.000257)\end{array}$ & $\begin{array}{l}-4.27 E-05 \\
(0.000262)\end{array}$ & $\begin{array}{l}-0.000376 \\
(0.000263)\end{array}$ & $\begin{array}{l}-3.80 E-05 \\
(0.000259)\end{array}$ \\
\hline $\begin{array}{l}\text { Gross savings rate (as \% } \\
\text { of GDP) }\end{array}$ & $\begin{array}{l}0.000385^{* * *} \\
(0.000128)\end{array}$ & $\begin{array}{l}0.000375^{* * *} \\
(0.000140)\end{array}$ & $\begin{array}{l}0.000333^{* *} \\
(0.000141)\end{array}$ & $\begin{array}{l}0.000396^{* * *} \\
(0.000139)\end{array}$ & $\begin{array}{l}0.000342^{* *} \\
(0.000140)\end{array}$ \\
\hline $\begin{array}{l}\text { Tax revenue (as \% of } \\
\text { GDP) }\end{array}$ & $\begin{array}{l}-0.001136^{* * *} \\
(0.000250)\end{array}$ & $\begin{array}{l}-0.00111^{* * *} \\
(0.000160)\end{array}$ & $\begin{array}{l}-0.00103^{* * *} \\
(0.000162)\end{array}$ & $\begin{array}{l}-0.00109^{* * *} \\
(0.000159)\end{array}$ & $\begin{array}{l}-0.001100^{* * *} \\
(0.000159)\end{array}$ \\
\hline Trade openness & $\begin{array}{l}7.99 \mathrm{E}-05^{* *} \\
(3.33 \mathrm{E}-05)\end{array}$ & $\begin{array}{l}7.78 E-05^{* *} \\
(3.53 E-05)\end{array}$ & $\begin{array}{l}7.91 \mathrm{E}-05^{* *} \\
(3.55 \mathrm{E}-05)\end{array}$ & $\begin{array}{l}7.34 E-05^{* *} \\
(3.53 E-05)\end{array}$ & $\begin{array}{l}6.67 \mathrm{E}-05^{*} \\
(3.58 \mathrm{E}-05)\end{array}$ \\
\hline Unemployment rate & $\begin{array}{l}0.001295^{* * *} \\
(0.000206)\end{array}$ & $\begin{array}{l}0.001173^{* * *} \\
(0.000212)\end{array}$ & $\begin{array}{l}0.001209^{* * *} \\
(0.000214)\end{array}$ & $\begin{array}{l}0.001015^{* * *} \\
(0.000212)\end{array}$ & $\begin{array}{l}0.001154^{* * *} \\
(0.000210)\end{array}$ \\
\hline EFW1 & $\begin{array}{l}0.011585^{* * *} \\
(0.003712)\end{array}$ & & & & \\
\hline $\mathrm{EFW} 1^{2}$ & $\begin{array}{l}-0.000532^{* *} \\
(0.000279)\end{array}$ & & & & \\
\hline$(r-g) \times E F W 1$ & $\begin{array}{l}1.37 E-05 \\
(6.87 E-05)\end{array}$ & & & & \\
\hline EFW2 & & $\begin{array}{l}0.012940^{* * *} \\
(0.004017)\end{array}$ & & & \\
\hline $\mathrm{EFW}^{2}$ & & $\begin{array}{l}-0.00110^{* * *} \\
(0.000373)\end{array}$ & & & \\
\hline$(r-g) \times \mathrm{EFW} 2$ & & $\begin{array}{l}-0.00023^{* * *} \\
(6.01 E-05)\end{array}$ & & & \\
\hline EFW3 & & & $\begin{array}{l}-0.013544^{* *} \\
(0.005299)\end{array}$ & & \\
\hline $\mathrm{EFW}^{2}$ & & & $\begin{array}{l}0.000952^{* * *} \\
(0.000339)\end{array}$ & & \\
\hline$(r-g) \times E F W 3$ & & & $\begin{array}{l}-0.000102^{*} \\
(5.64 \mathrm{E}-05)\end{array}$ & & \\
\hline EFW4 & & & & $\begin{array}{l}0.031972^{* * *} \\
(0.005828)\end{array}$ & \\
\hline $\mathrm{EFW}^{2}$ & & & & $\begin{array}{l}-0.00224^{* * *} \\
(0.000421)\end{array}$ & \\
\hline$(r-g) \times \mathrm{EFW} 4$ & & & & $\begin{array}{l}4.43 E-05 \\
(8.01 E-050)\end{array}$ & \\
\hline EFW5 & & & & & $\begin{array}{l}0.006393 \\
(0.009240)\end{array}$ \\
\hline $\mathrm{EFW}^{2}$ & & & & & $\begin{array}{l}-0.000210 \\
(0.000667)\end{array}$ \\
\hline$(r-g) \times E F W 5$ & & & & & $\begin{array}{l}-0.000236^{* * *} \\
(6.80 E-05)\end{array}$ \\
\hline $\begin{array}{l}\text { Redundant fixed effects } \\
\text { tests (prob) }\end{array}$ & $\begin{array}{l}199.837128 \\
(0.0000)\end{array}$ & $\begin{array}{l}203.073872 \\
(0.0000)\end{array}$ & $\begin{array}{l}209.428482 \\
(0.0000)\end{array}$ & $\begin{array}{l}206.846867 \\
(0.0000)\end{array}$ & $\begin{array}{l}201.134660 \\
(0.0000)\end{array}$ \\
\hline Hausman test & $\begin{array}{l}72.567801 \\
(0.0000)\end{array}$ & $\begin{array}{l}83.187496 \\
(0.0000)\end{array}$ & $\begin{array}{l}65.382413 \\
(0.0000)\end{array}$ & $\begin{array}{l}72.041878 \\
(0.0000)\end{array}$ & $\begin{array}{l}70.647063 \\
(0.0000)\end{array}$ \\
\hline Adj. R-squared & 0.970054 & 0.969739 & 0.969494 & 0.969941 & 0.969637 \\
\hline F-statistic & 481.0456 & 475.8991 & 471.2806 & 478.8391 & 479.3310 \\
\hline Prob(F-statistic) & 0.000000 & 0.000000 & 0.000000 & 0.000000 & 0.000000 \\
\hline
\end{tabular}

Dependent variable is Gini of net income. All regressions report panel fixed effects. Standard errors are in parentheses and $*^{* *}, *^{* *}, *$, respectively, mean significant at $1 \%, 5 \%$, and $10 \%$ level

Source Research calculations 
Table 8 2SLS estimation results of five areas of economic freedom

\begin{tabular}{|c|c|c|c|c|c|}
\hline Variable & (1) & (2) & (3) & (4) & (5) \\
\hline$(r-g)$ & $\begin{array}{l}0.008810^{*} \\
(0.005210)\end{array}$ & $\begin{array}{l}0.002270^{* * *} \\
(0.000434)\end{array}$ & $\begin{array}{l}0.005952^{* *} \\
(0.003067)\end{array}$ & $\begin{array}{l}-0.001228 \\
(0.001123)\end{array}$ & $\begin{array}{l}-0.000196 \\
(0.001417)\end{array}$ \\
\hline Lag GDP/capita & $\begin{array}{l}-3.08 \mathrm{E}-06^{* *} \\
(1.49 \mathrm{E}-06)\end{array}$ & $\begin{array}{l}-1.07 E-06^{* * *} \\
(3.99 E-07)\end{array}$ & $\begin{array}{l}8.18 \mathrm{E}-07 \\
(9.16 \mathrm{E}-07)\end{array}$ & $\begin{array}{l}-4.80 \mathrm{E}-07 \\
(5.95 \mathrm{E}-07)\end{array}$ & $\begin{array}{l}-2.73 E-06^{* *} \\
(1.14 E-06)\end{array}$ \\
\hline Govt. spending (as \% of GDP) & $\begin{array}{l}0.003548 \\
(0.002429)\end{array}$ & $\begin{array}{l}-0.000357 \\
(0.000394)\end{array}$ & $\begin{array}{l}-0.000784 \\
(0.000744)\end{array}$ & $\begin{array}{l}0.000219 \\
(0.000537)\end{array}$ & $\begin{array}{l}0.000634 \\
(0.000863)\end{array}$ \\
\hline Inflation & $\begin{array}{l}-0.000463 \\
(0.000373)\end{array}$ & $\begin{array}{l}0.000241^{*} \\
(0.000125)\end{array}$ & $\begin{array}{l}-0.000784 \\
(0.000744)\end{array}$ & $\begin{array}{l}0.000660^{* *} \\
(0.000231)\end{array}$ & $\begin{array}{l}-0.000809 \\
(0.000503)\end{array}$ \\
\hline Population growth rate & $\begin{array}{l}-0.004410 \\
(0.003564)\end{array}$ & $\begin{array}{l}0.001555 \\
(0.001052)\end{array}$ & $\begin{array}{l}0.002987 \\
(.002300)\end{array}$ & $\begin{array}{l}7.75 E-05 \\
(0.001365)\end{array}$ & $\begin{array}{l}-0.001901 \\
(0.002342)\end{array}$ \\
\hline $\begin{array}{l}\text { Natural resource rent (as \% of } \\
\text { GDP) }\end{array}$ & $\begin{array}{l}-0.001108 \\
(0.000803)\end{array}$ & $\begin{array}{l}-8.43 E-05 \\
(0.000286)\end{array}$ & $\begin{array}{l}0.001029 \\
(0.000846)\end{array}$ & $\begin{array}{l}-0.001506^{* *} \\
(0.000606)\end{array}$ & $\begin{array}{l}-0.001616^{*} \\
(0.000900)\end{array}$ \\
\hline Gross savings rate (as \% of GDP) & $\begin{array}{l}0.000749^{*} \\
(0.000402)\end{array}$ & $\begin{array}{l}0.000545^{* * *} \\
(0.000167)\end{array}$ & $\begin{array}{l}0.128700^{* * *} \\
(0.040032)\end{array}$ & $\begin{array}{l}0.000703^{* * *} \\
(0.000228)\end{array}$ & $\begin{array}{l}0.001111^{* *} \\
(0.000440)\end{array}$ \\
\hline Tax revenue (as \% of GDP) & $\begin{array}{l}-0.00205^{* * *} \\
(0.000556)\end{array}$ & $\begin{array}{l}-0.00210^{* * *} \\
(0.000256)\end{array}$ & $\begin{array}{l}-0.003842^{* *} \\
(0.001546)\end{array}$ & $\begin{array}{l}-0.00153^{* * *} \\
(0.000339)\end{array}$ & $\begin{array}{l}-0.0015^{* * *} \\
(0.000460)\end{array}$ \\
\hline Trade openness & $\begin{array}{l}0.000106 \\
(9.70 E-05)\end{array}$ & $\begin{array}{l}0.000124^{* * *} \\
(4.31 \mathrm{E}-05)\end{array}$ & $\begin{array}{l}-2.05 E-05 \\
(0.000118)\end{array}$ & $\begin{array}{l}1.52 \mathrm{E}-05 \\
(6.96 \mathrm{E}-05)\end{array}$ & $\begin{array}{l}0.000100 \\
(8.61 E-05)\end{array}$ \\
\hline Unemployment rate & $\begin{array}{l}0.002446^{* * *} \\
(0.000810)\end{array}$ & $\begin{array}{l}0.001077^{* * *} \\
(0.000261)\end{array}$ & $\begin{array}{l}0.012603^{* * *} \\
(0.003539)\end{array}$ & $\begin{array}{l}0.000763^{* *} \\
(0.000381)\end{array}$ & $\begin{array}{l}0.000541 \\
(0.000511)\end{array}$ \\
\hline EFW1 & $\begin{array}{l}0.295454^{*} \\
(0.167960)\end{array}$ & & & & \\
\hline $\mathrm{EFW} 1^{2}$ & $\begin{array}{l}-0.018695 \\
(0.011420)\end{array}$ & & & & \\
\hline$(r-g) \times E F W 1$ & $\begin{array}{l}-0.001254^{*} \\
(0.000741)\end{array}$ & & & & \\
\hline EFW2 & & $\begin{array}{l}0.093011^{* * *} \\
(0.029822)\end{array}$ & & & \\
\hline $\mathrm{EFW}^{2}$ & & $\begin{array}{l}-0.00828^{* * *} \\
(0.002879)\end{array}$ & & & \\
\hline$(r-g) \times E F W 2$ & & $\begin{array}{l}-0.00040^{* * *} \\
(7.67 \mathrm{E}-05)\end{array}$ & & & \\
\hline EFW3 & & & $\begin{array}{l}-0.341668^{* *} \\
(0.173638)\end{array}$ & & \\
\hline $\mathrm{EFW}^{2}$ & & & $\begin{array}{l}0.019706^{*} \\
(0.010142)\end{array}$ & & \\
\hline$(r-g) \times E F W 3$ & & & $\begin{array}{l}-0.000708^{*} \\
(0.000364)\end{array}$ & & \\
\hline EFW4 & & & & $\begin{array}{l}0.195123^{* * *} \\
(0.067223)\end{array}$ & \\
\hline $\mathrm{EFW}^{2}$ & & & & $\begin{array}{l}-0.01211^{* * *} \\
(0.004460)\end{array}$ & \\
\hline$(r-g) \times E F W 4$ & & & & $\begin{array}{l}0.000153 \\
(0.000149)\end{array}$ & \\
\hline EFW5 & & & & & $\begin{array}{l}-0.56761^{* *} \\
(0.263736)\end{array}$ \\
\hline $\mathrm{EFW}^{2}$ & & & & & $\begin{array}{l}0.040889^{* *} \\
(0.018762)\end{array}$ \\
\hline$(r-g) \times E F W 5$ & & & & & $\begin{array}{l}4.34 E-07 \\
(0.000200)\end{array}$ \\
\hline Observations & 1360 & 1360 & 1358 & 1359 & 1360 \\
\hline Number of countries & 80 & 80 & 80 & 80 & 80 \\
\hline Adj. R-squared & 0.840632 & 0.962136 & 0.848207 & 0.940148 & 0.878289 \\
\hline F-statistic & 475.1823 & 481.1154 & 474.1967 & 475.2936 & 478.9523 \\
\hline Prob (F-statistic) & 0.000000 & 0.000000 & 0.000000 & 0.000000 & 0.000000 \\
\hline
\end{tabular}

Dependent variable is Gini of net income. All regressions report panel fixed effects. Standard errors are in parentheses and $* * * * * * *$, respectively, mean significant at $1 \%, 5 \%$, and $10 \%$ level

Source Research calculations 


\section{Appendix B}

See Tables 9 and 10.

Table 9 List of countries

\begin{tabular}{|c|c|c|c|c|}
\hline \multicolumn{2}{|c|}{ High-income countries } & \multicolumn{2}{|c|}{ Middle-income countries } & \multirow{2}{*}{$\begin{array}{l}\text { Low-income countries } \\
\text { Rwanda }\end{array}$} \\
\hline Australia & Japan & Argentina & Jordan & \\
\hline Austria & Korea & Armenia & Malaysia & Uganda \\
\hline Belgium & Latvia & Bangladesh & Mexico & Gambia, The \\
\hline Canada & Lithuania & Bosnia and Herz. & Morocco & Tanzania \\
\hline Chile & Malta & Bolivia & Nigeria & Kenya \\
\hline Croatia & Netherlands & Brazil & Nicaragua & Zambia \\
\hline Cyprus & New Zealand & Bulgaria & Pakistan & \\
\hline Czech Rep & Norway & China & Panama & \\
\hline Denmark & Panama & Colombia & Paraguay & \\
\hline Estonia & Poland & Costa Rica & Philippines & \\
\hline Finland & Portugal & Dominican Republic & Peru & \\
\hline France & Slovakia & Egypt & Romania & \\
\hline Germany & Slovenia & Georgia & Russia & \\
\hline Greece & Spain & Guatemala & South Africa & \\
\hline Hungary & Switzerland & Honduras & Sri Lanka & \\
\hline Iceland & Sweden & Indonesia & Thailand & \\
\hline Israel & United States & India & Turkey & \\
\hline Ireland & United Kingdom & Iran & Ukraine & \\
\hline Italy & Uruguay & Jamaica & Vietnam & \\
\hline
\end{tabular}

Table 10 List of countries results of top $10 \%$ income share

\begin{tabular}{|c|c|c|c|}
\hline Australia & Egypt & Jordan & Russia \\
\hline Austria & Estonia & Korea & Slovakia \\
\hline Belgium & Finland & Latvia & Slovenia \\
\hline Bosnia \& Herz. & France & Lithuania & Spain \\
\hline Brazil & Germany & Malaysia & Sweden \\
\hline Bulgaria & Greece & Malta & Switzerland \\
\hline Canada & Hungary & Moldova & Turkey \\
\hline China & India & Netherlands & Thailand \\
\hline Chile & Iceland & New Zealand & United Kingdom \\
\hline Croatia & Iran & Norway & United States \\
\hline Cyprus & Ireland & Portugal & \\
\hline Czech Republic & Italy & Poland & \\
\hline Denmark & Japan & Romania & \\
\hline
\end{tabular}




\section{References}

Acemoglu D, Robinson JA (2015) the rise and decline of general laws of capitalism. J Econ Perspect 29(1):3-28

Acemoglu D, Johnson S, Robinson JA (2005) Institutions as a fundamental cause of long-run growth. Handbook Economic Growth 1:385-472

Ahmad M (2017) Economic freedom and income inequality: does political regime matter? Economies 5(2):18

Albanesi S (2007) Inflation and inequality. J Monetary Econ 54(4):1088-1114

Alesina A, Angeletos GM (2005) Corruption, inequality, and fairness. J Monetary Econ 52(7):1227-1244

Apergis Nicholas, Cooray Arusha (2015) Economic Freedom and Income Inequality: evidence from a panel of Global economies - a linear and a non-linear long-run analysis. Manchester School 85:88-105

Apergis N, Dincer O, Payne JE (2014) Economic freedom and income inequality revisited: evidence from a panel error correction model. Contemporary Economic Policy 32(1):67-75

Ashby NJ, Sobel RS (2008) Income inequality and economic freedom in the U.S. states. Public Choice 134:329-346

Bennett DL, Nikolaev B (2017) On the ambiguous economic freedom-inequality relationship. Empirical Economics 53(2):717-754

Bennett DL, Vedder RK (2013) A dynamic analysis of economic freedom and income inequality in the 50 US states: empirical evidence of a parabolic relationship. J Regional Analysis Policy 43(1):42-55

Berggren N (1999) Economic freedom and equality: friends or foes? Public Choice 100(3-4):203-223

Cameron AC, Trivedi PK (2009) Microeconometrics using stata. Stata press, College Station

Carter J (2007) an empirical note on economic freedom and income inequality. Public Choice 130:163-177

Chong A, Gradstein M (2007) Inequality and institutions. Rev Economics Statistics 89(3):454-465

Clark JR, Lawson RA (2008) The impact of economic growth, tax policy and economic freedom on income inequality. Journal Private Enterprise Fall 24:23-31

Constantine C (2017) Economic structures, institutions and economic performance. J Economic Structures 6(1):2

De Soto H (2000) The mystery of capital: why capitalism triumphs in the west and fails every-where else. Basic Book, New York

Deininger K, Squire L (1996) A new data set measuring income inequality. World Bank Econ Rev 10:565-591

Doerrenberg P, Peichl A (2014) The impact of redistributive policies on inequality in OECD countries. Appl Econ 46(17):2066-2086

Doucouliagos C, Ulubasoglu MA (2006) Economic freedom and economic growth: does specification make a difference? Eur J Polit Econ 22(1):60-81

Facchini F, Couvreur S (2015) Inequality: the original economic sin of capitalism? An Evaluation of Thomas Piketty's" Capital in the twenty-first century". Eur J Polit Econ 39:281-287

Facchini F, Melki M (2014) Political ideology and economic growth: evidence from the French democracy. Econ Inq 52(4):1408-1426

Fakir AM, Ahmad AU, Hosain KM, Hossain MR, Gani RS (2017) The comparative effect of corruption and Piketty's second fundamental law of capitalism on inequality. Econ Analysis Policy 55:90-105

Graafland J, Lous B (2018) Economic freedom, income inequality and life satisfaction in OECD countries. J Happiness Stud 19(7):2071-2093

Gupta S, Davoodi H, Alonso-Terme R (2002) Does corruption affect income inequality and poverty? Econ Gov 3(1):23-45

Gwartney J, Lawson R (2003) The concept and measurement of economic freedom. Eur J Polit Econ 19(3):405-430

Gwartney J, Holcombe R, Lawson R (2004) Economic freedom, institutional quality, and cross- country differences in income and growth. Cato J 24:205-233

Islam MR (2018) Wealth inequality, democracy and economic freedom. J Comparative Econ 46(4):920-935

Jones Cl (2015) Pareto and Piketty: the macroeconomics of top income and wealth inequality. J Econ Perspect 29(1):29-46

Karabegovic A, McMahon F (2005) Economic freedom of North America. 2005 annual report. The Frasier Institute, Vancouver

Krusell P, AA Smith Jr (2015) Is Piketty's second law of capitalism fundamental? J Polit. Econ 123(4):725-748

Kuttner R (2014) What Piketty leaves out. American Prospect, 30. https://prospect.org/culture/books/piketty-leaves/

Lustig N, Lopez-Calva LF, Ortiz-Juarez E (2013) Declining inequality in Latin America in the 2000s: the cases of Argentina, Brazil, and Mexico. World Dev 44:129-141

Mankiw NG (2015) Yes, r > g. So what? Econ Rev 105(5):43-47

Marx K (1867) In: Frederick, Engels, Ernest, Untermann (Eds.), Capital: A Critique of Political Economy, Vol. I. The Process of Capitalist Production. Moore Samuel and Aveling Edward, Trans. 1906. Library of Economics and Liberty. Retrieved Oct 25, 2016 from the World Wide Web: http://www.econlib.org/library/YPDBooks/Marx/mrxCpA.html

Milanovic B (2014) The return of "patrimonial capitalism": a review of Thomas Piketty's Capital in the twenty-first century. J Econ Literature 52(2):519-534

Montinola GR, Jackman RW (2002) Sources of corruption: a cross-country study. Br J Polit Sci 32(1):147-170

Perez-Moreno S, Angulo-Guerrero MJ (2016) Does economic freedom increase income inequality? Evidence from the EU countries. J Econ Policy Reform 19:327-347

Piketty T (2014) Capital in the twenty-first century (trans: Goldhammer A). Belknap, Cambridge

Piketty T (2015) Putting distribution back at the center of economics: reflections on capital in the twenty-first century. J Econ Perspect 29(1):67-88

Piketty T, Zucman G (2014) Capital is back: wealth-income ratios in rich countries 1700-2010. Q J Econ 129(3):1255-1310

Ricardo D (1817) Principles of political economy and taxation, 3rd. Principi dell'Economia Politica e delle imposte. Retrieved Oct 25, 2016 from the World Wide Web: http://www.econlib.org/library/Ricardo/ricP.html

Roine J, Vlachos J, Waldenstro D (2009) The long-run determinants of inequality: what can we learn from top income data? J Public Econ 93:974-988

Rothstein B, Uslaner EM (2005) All for all: equality, corruption, and social trust. World Polit 58(01):41-72

Scully GW (2002) Economic freedom, government policy and the trade-off between equity and economic growth. Public Choice 113:77-96 
Smith A (1776) An Inquiry into the Nature and Causes of the Wealth of Nations. Methuen \& Co. Ltd., London Solt F (2014) The Standardized World Income Inequality Database. Working paper. SWIID Version 5.0. Retrieved from: http://myweb.uiowa.edu/fsolt/ papers/Solt2014 (Accessed 24.05.16)

Stern DI (2004) The rise and fall of the environmental Kuznets curve. World Dev 32(8):1419-1439

Stiglitz JE (2012) The price of inequality: How today's divided society endangers our future. WW Norton \& Company, New York

Sturm Jan-Egbert, De Haan Jakob (2015) Income inequality, capitalism, and ethno-linguistic fractionalization. Am Econ Rev 105:593-597

Tao S, Zheng T, Lianjun T (2008) An empirical test of the environmental Kuznets curve in China: a panel cointegration approach. China Econ Rev 19(3):381-392

Weil DN (2015) Capital and wealth in the twenty-first century. Am Econ Rev 105(5):34-37

World Bank (2018) New country classifications by income level: 2017-2018. http://datatopics.worldbank.org/world-devel opment-indicators/images/figures-png/world-by-income-sdg-atlas-2018pdf

\section{Publisher's Note}

Springer Nature remains neutral with regard to jurisdictional claims in published maps and institutional affiliations.

\section{Submit your manuscript to a SpringerOpen ${ }^{\circ}$} journal and benefit from:

- Convenient online submission

- Rigorous peer review

- Open access: articles freely available online

- High visibility within the field

- Retaining the copyright to your article

Submit your next manuscript at $\boldsymbol{\Delta}$ springeropen.com 